\title{
COMPETITIVENESS ANALYTIC OF NIGERIA AND SINGAPORE | NATIONAL PRODUCTIVITY AND ECONOMY
}

\author{
Ayodele A. Otaiku \\ DPA, DBA and Ph.D Scholar \\ Web-Link | https://nda-ng.academia.edu/AyodeleOtaiku | https://orcid.org/0000-0002-4010-8134 \\ Faculty of Social Science, Department of Geography and Environmental Management, \\ University of Port Harcourt, Choba, Port Harcourt, Rivers States, Nigeria. \\ +234803 3721219 WhatsApp | Skype @ AyodeleOtaiku | aotaiku@gmail.com
}

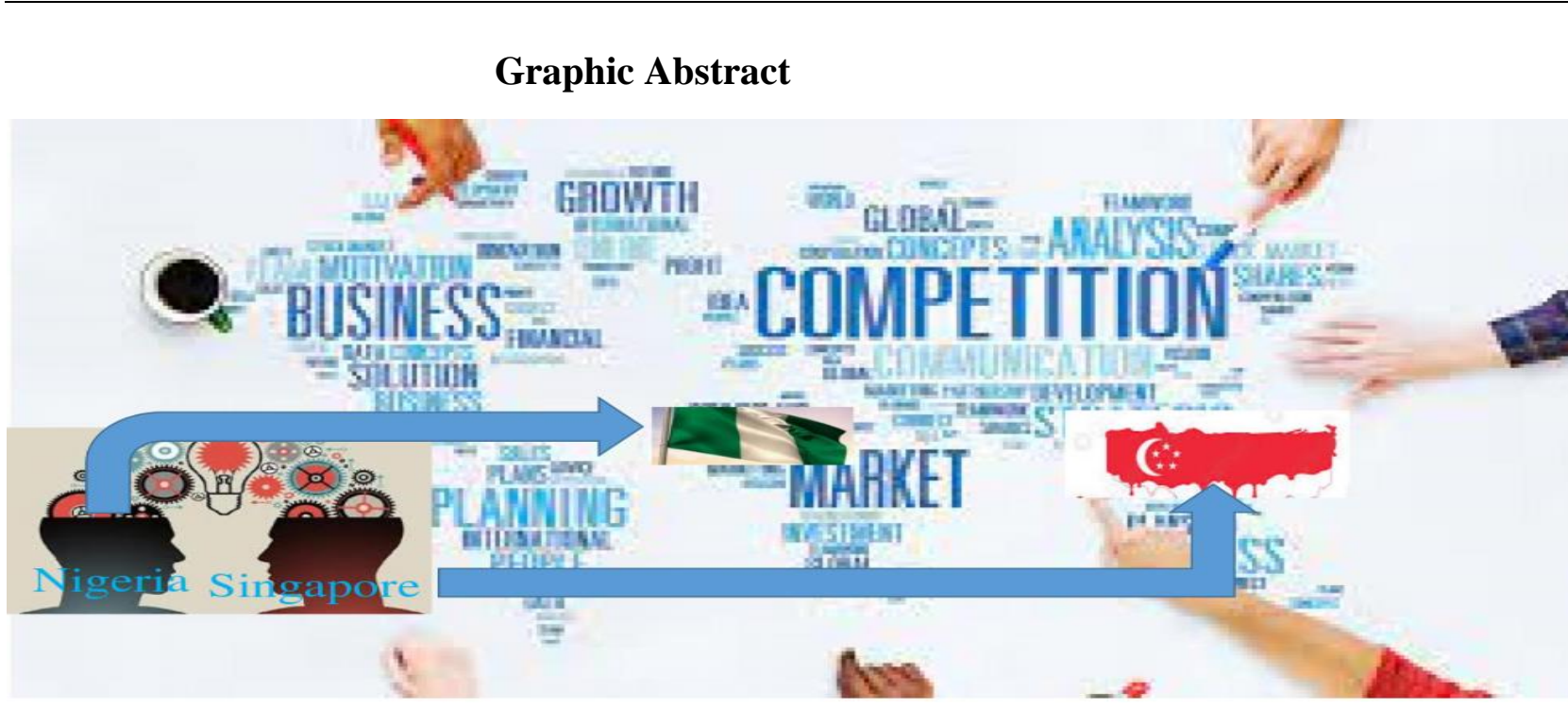

ABSTRACT | Competition power of a country can simply be defined as the ability to compete relative to its rivals and where Singapore and Nigeria were case studies. The effective policies to increase the level of prosperity and how to translate information about specific strengths and weaknesses across the many factors that drive competitiveness was the crux of the study. The competitiveness analytic identify uncertainties (more raking competitiveness metrics); seek alternative framing of problems; build hybrids (objects such as indicators or policy formulation); and human capacity to link knowledge to action for national productivity and country's share of world markets for its products and services, provide its residents with a rising standard of living and a high employment on a sustainable basis was the resultant impacts of competitiveness. Value results from a total effort, rather than from 'one isolated step' in the process for all indexes of competitiveness. Singapore had better competitiveness index than Nigeria with global ranking as the most competitive nation in the world, 2020.The crux of $21^{\text {st }}$ century competitiveness ranking should focus on the unification of competitiveness indicators and the development of integral competitiveness fundamentals that, can capture the traditional and emerging indicators like 'Climate changes', 'Pollution', 'Cyber security' and 'Hybrid warfare' was accentuated as spatial polysingularity framework for the future study of competitiveness.

KEYWORDS | Nigeria, Singapore, spatial polysingularity, innovation, entrepreneurship, networking, competitiveness, development, growth, productivity, reforms, value, global competitiveness index (GCI), wicked problem, economic, internet of things (IoTs), World economic forum. 


\section{INTRODUCTION}

Online ISSN: 2053-4027(Online)

Competitiveness is the ability of the country to redistribute the value created in the global economy in its favour. This is ensured through providing conditions for creating greater value added to maintain a high living standard in the country. The Fourth industrial revolution (Industry 4.0) quickly leads to significant changes in all sectors of the economy, both at the national and macroeconomic levels. World Economic Forum ${ }^{1}$ (Shaping the Future of Digital Economy and New Value Creation, 2019), asserted more than $60 \%$ of global GDP is expected to be digitized by 2022 . Scholars asserted that, $70 \%$ of the new values created in the economy over the next decade will be based on digital platforms and $10 \%$ increase in the country's digitalization indicator results in a $0.75 \%$ increase in Gross domestic product (GDP) per capita, as well as a significantly reduced unemployment rate. Today, about a half of the world's population is not involved in the digital economy, which slows down the Internet growth.

\section{Definitions}

Competitiveness was coined in the 70s of the twentieth century when American economists, under the evidence of severe trade battle between American and Japanese companies, undertook the first attempts to determine the degree of competitiveness between the rival economies (WziątekKubiak, 2003). The oil crisis and the associated loss of comparative advantage by some industries in the developed countries triggered attention in this economic category (Lech, 2001;Adamkiewicz -Drwiłło, 2002). The competitiveness of a company means adapting its products to the market and competition requirements, particularly in terms of product range, quality, price as well as optimal sales channels and methods of promotion. Altomonte et al., (2012) asserted that, the external or inter- national competitiveness is the ability to exchange the goods and services that are abundant in-home country for the goods and services that are scarce in this country (Ajitabh, Momaya, 2004). Country's competitiveness is the degree to which it can, under free and fair market conditions, produce goods or services meeting the test of international markets, while simultaneously maintaining and expanding the real incomes of its population over the longer term (Bobba et al., 1971).

Competitiveness is the ability of nations, regions and companies to generate wealth being the precondition for high wages (Buckley et al., 1988). A firm's competitiveness means its ability to produce and sell products and services of superior quality and lower costs than its domestic and international competitors. Competitiveness is a firm's long-run profit performance and its ability to compensate its employees and provide superior returns to its owners. (Chao-Hung, Li-Chang, 2010). A firm's competitiveness is its economic strength against its rivals in the global marketplace where products, services, people and innovations move freely despite the geo-graphical boundaries (European Commission, 2001). Competitiveness of a nation is the ability of an economy to provide its population with high and rising standards of living and high rates of employment on a sustainable basis (Flejterski, 1984). Competitiveness is the capacity of the sector, industry or branch to design and sell its goods at prices, quality and other features that are more attractive than the parallel characteristics of the goods offered by the competitors (Krugman, 1990, 1994). If competitiveness has any meaning, it is simply just another way to 'express productivity' because, the ability of a country to improve its living standard depends almost entirely on its ability to raise its productivity. Competitiveness is meaningless word when applied to national economies (Porter, 1990). The only meaningful concept of competitiveness at the national level is national productivity.

\footnotetext{
${ }^{1}$ https://www.weforum.org/platforms/shaping-the-future-of-digital-economy-and-new-value-creation.
} 
Competitiveness is an ability of an economy to provide its residents with a rising standard of living and a high employment on a sustainable basis (Porter et al., 2008). The most intuitive definition of competitiveness is a country's share of world markets for its products. This makes competitiveness a zero-sum game, because one country's gain comes at the expense of others (Scott,). National competitiveness is a country's ability to create, produce, distribute, and/or service products in international trade while earning rising returns on its resources (Tyson D'Andrea, 1992).

Competitiveness is our ability to produce goods and services that meet the test of international competition while our citizens enjoy a standard of living that is both rising and sustainable (WEF Schwab, Sala-i-Mart, 2013). Competitiveness is the set of institutions, policies, and factors that determine the level of productivity of a country to achieve sustained high rates of growth in GDP per capita.

\section{What is Wicked Problems in Policy Development?}

The terminology of 'wicked problems' is now firmly entrenched in the language of policy researchers and policy practitioners (Rittel and Webber, 1973; Roberts, 2000; APSC, 2007; Head, 2010).Wicked problems definitions in literatures tend towards the assumption that, they are highly complex; information about the likely impact of any interventions is limited; and there is a distinct lack of agreement on their causes and the best ways of addressing these seemingly chronic and intractable problems. The typology of wicked problems cited includes: homelessness (Klodawsky,2009), child protection (Gillingham and Humphreys,2010), climate change (Lazarus, 2009), people smuggling (Gallagher,2015), urban congestion (Greyling et al.,2016), illicit drug use (Seddon,2016),sustainability (Clark,2007), environment (Duckett et al.,2016; Levin et al.,2009; Ayers and Dodman,2010; Berkes,2009), agriculture (Fischer et al.,2012; Peterson,2009; Van Latesteijn, and Rabbingeb (2012) and Otaiku, 2020), food Security (Lang and Barling, 2012; Dentoni et al.,2012). and gender economic inequality (Turnbull, 2010) and National interest (Otaiku, $2020 \mathrm{a}, \mathrm{b})$.

The searches for 'solutions' are at the heart of politics (Rittel and Webber,1973) but conflict between multiple publics is a major barrier to the type of unitary planning that is needed to address wicked problems. Yet if 'politics' is part of the explanation for policy responses failing to some degree in addressing wicked problems, there is far more to politics than simply conflicts between different views. Politics also involves matters such as protecting political reputation, controlling agendas and carving out particular ideological trajectories. The study of 'competitiveness' as a shaper of responses to wicked problems has tended to be cross disciplinary, ad-hoc and fragmented often giving way (understandably) to specific areas of interest in relation to wicked problems (competiveness). The problem definition is spatial, requiring consensus to have a meaning (carving out particular ideological trajectories), contexts specific situation between different views (polysingularity) for solution execution in the continuum (determinants of competiveness). The literature on wicked problems has to put it crudely- focused on differentiating (spatial) between 'exceptionally tough' problems and various others which are much less so. Such finer-grained analyses have played out through arguments that problems are not simply tame or wicked (Heifetz, 1994; Head and Alford, 2015), there are degrees of wickedness (Koppenjan and Klijn,2004; Roberts, 2000), and indeed there are super-wicked problems (Lazarus, 2009) where time is running out (arguably climate change) which I used the metaphor called polysingularity

\section{Spatial Poly Singularity}

Nation interest should be mutual understanding through discourse and are based on the premise that, 'decision making is an iterative process' with learning taking place as 'stakeholder preferences are developed or discovered' when 'confronting choices' (Stephenson and Shabman,2007) termed 
polysingularity. Spatial polysingularity, an engagement methodology embedding those 'value judgments' by participants 'competitiveness context' appropriate domain of the 'discourse and collaborative negotiations' since addressing wicked problems involves improving negotiation processes (Norton, 2005) in policy development. This paper argument is that 'competitiveness is the set of institutions, policies, and factors that determine the level of productivity of a country to achieve sustained high rates of growth in GDP per capita and 'provides information for adaptive solution' using framework - spatial poly singularity construct. The maxim of spatial polysingularity theory 'when deciding what to do, one is also deciding what not to do'. The solving of problems undertaken after an exploration of values of their implications for society are explored for suitable goals are identified. It is an adaptive management that involves feedback loops defined by the problems contexts - specific situation termed 'integral competitive ranking', that it addresses, rather than the disciplines involved incorporating knowledge from those who move knowledge to action.

It is highly integrated and multidisciplinary decision value creation framework construct that encapsulate the typology of wicked problems for solution development 'craft':

1.Wicked problems it is difficult to decide, what facts to gather without first discussing values.

2. When you think what to do, think of what not to, do because of the inability of science to exercise mastery over eventual outcomes because of confounding influences of 'spatial and temporal fluctuations and variability'. Spatial polysingularity framework (Figure 1) involves recursive thinking to develop strategies for collaboration better knowledge consultation and use of third parties affirmed by scholars (Head,2008; Roberts,2000) like World Economic Forum (economic development), United Nations (peace treaty) etc called 'Stakeholders' improved knowledge transmission and integration within networks (Webber and Khademian,2008). Contexts specific situations requires finding iterative and adaptive ways of continually reassessing and 'renegotiating solutions' rather than attempting to 'solve' problems (Head, 2014); and governance strategies based on new ways of observing and enabling (Termeer et al,2015) what I called 'Scenarios', altogether a metaphor - Spatial polysingularity construct. A feature of these and numerous other studies is that 'politics tends to appear on an ad-hoc basis, usually within studies, that have specific concerns and approaches (competiveness). For example, some focus on the institutions and processes of government. Spatial polysingularity is a challenge to quasirationalistic ways of working affirmed by Head and Alford (2015) to focus essentially on public administration/management, opportunities and the ways in which addressing wicked problems with high levels of uncertainty, diversity and disagreement for a consensus solution. Human capital networking's an integral aspect of spatial polysingularity construct affirmed by Ferlie et al., (2011) 'on the capacity and potential of policy networks to address wicked problems'. Other scholars address power of political elites (influencers of foreign policy of a nation) and the challenges of decision making, including the management of multiple expectations and the influence of political ideology (Durant and Legge, 2006).

\section{Boundary Organization | Competitiveness foreign policy}

Dominating the development and application of the technologies of the industrial revolution made Great Britain, and later the United States, super-powers for a period spanning more than a century. As Great Britain learned, however, such dominance can be fleeting, and the consequences of falling behind can be devastating. Thus, continued dominance of the development and application of information technology is not just in the short-run military interests of the United States; it is extremely important to its long-run success as the world's only superpower and the 'anatomy' of grand strategy today. How engagement can change the identification and framing of problems of foreign policy school of thoughts: realist school (Dunne and Schmidt, 2005); behaviourist school (Agreen,20I0); Marxist school of thought (Obajili and Obi,2003); and liberal 
approach (Burchill, 2005) with the critical engagement use of a boundary organization, which is a bridging institution which links suppliers and users of knowledge and recognizes the importance of location-specific contexts (Ruttan et al.,1994) like competiveness determinants. The critical success factors for boundary organization are: first, they must provide incentives to produce boundary objects, such as decisions or products that reflect the input of different perspectives. Second, they involve participation from actors across boundaries; third, they have lines of accountability to the various organizations spanned (by the boundary organization) reported by Guston, 2001; Batie, 2008. Competitiveness can be a "boundary object" but only if a better understanding of physical and socioeconomic conditions is desirable from all parties' perspectives (boundary organization) ranking metrics for competitiveness, like world economic forum etc.

What is a desirable future 'value' is arrived at through a negotiated process among stakeholders? Thus, a boundary organization by combining tacit and explicit knowledge can co-create new, transformational knowledge and shared understanding which may be critical to the innovation in the policy process (Conklin, 2006; Guston, 2001; Peterson, 2008). This co-creation process, by allowing participants (determinants of competitiveness) to critically reflect on each other's views, enables participants to reflect not only on their own preferences and viewpoints but also on how they might be changed (White, 1994) with each scenario. Scenario work enhances integration across 'themes' and serves as a mechanism for interdisciplinary work that engages stakeholders (Figure 1). With dynamic scenario development, alternative futures are identified (sometimes with forecast models), and then the analysis works backward in time to identify crucial pathways that avoid undesirable outcomes or result in desirable ones (Norton, 2005; Jacobs et al., 2005) ; identify uncertainties; seek alternative framing of problems; build hybrids (objects such as indicators or maps that contain policy information); and build capacity to link knowledge to action (Miller,1999). The methodology is critical engagement of location specific contexts (boundary organization) and application of post-normal science that addresses uncertainties (Funtowicz and Ravetz,1993; Nowotny et al.,2001) like sustainability science, that seeks to inform and facilitate a societal transition toward sustainable development (Clark,2007) using dynamic scenario development.

\section{Nigeria}

Nigeria is the largest oil producer in Africa and holds the largest natural gas reserves on the continent and was the world's fifth-largest exporter of liquefied natural gas (LNG) in 2018. ${ }^{2}$ Although Nigeria is the leading crude oil producer in Africa, production is affected by sporadic supply disruptions. Nigeria's crude oil and natural gas resources are the mainstay of the country's economy. Because Nigeria heavily depends on oil revenue, its economy is noticeably affected by crude oil price changes. The International Monetary Fund (IMF) projects that Nigeria's crude oil and natural gas exports earned $\$ 55$ billion in 2018, which is $\$ 23$ billion higher than in $2016 .{ }^{3}$ The growth in export revenue, which can be partly attributed to the rebound in crude oil prices, has helped improve Nigeria's fiscal position. However, Nigeria's fiscal deficit remained flat at $4 \%$ of its gross domestic product (GDP) because of a significant increase in capital expenditures and lower-than-expected non-oil revenue collection, in spite of improvements to the country's tax administration. The Nigerian government still heavily relies on crude oil and natural gas revenue; its non-oil revenue comprises only $3.4 \%$ of GDP, one of the lowest in the world. ${ }^{4}$

\footnotetext{
${ }^{2}$ BP 2019, Statistical Review of World Energy, June 2019.

${ }^{3}$ International Monetary Fund, 2019 Article IV Consultation, IMF Country Report no. 19/92.

${ }^{4}$ International Monetary Fund, 2019 Article IV Consultation, IMF Country Report no. 19/92.
} 
In Nigeria's oil revenues constitute an enormous opportunity for sustainable growth and rising living standards only if the institutional environment is supportive of growth. The catastrophic failure of public policy in Nigeria was that oil windfalls were not transformed into a higher level of sustainable consumption. Collier (2008) asserted, that, policy during the 'oil booms' ensured that future consumption would be lower, as public policy was more consumption oriented rather than investing in productive assets. Currently, Nigeria is characterised by institutional environment unsupportive of a competitive economy due to global concerns about insufficient protection of property rights, undue influence, poor ethics, high levels of corruption, government spending that is perceived as wasteful, as well as grave security challenge that has paralysed the economy of the once thriving North eastern region of the country and spreading nationwide.

\section{Singapore}

In 1965, Singapore became independent and a poor small nation (about $700 \mathrm{~km}^{2}$ ) tropical island with few natural resources, little fresh water, rapid population growth, substandard housing and recurring conflict among the ethnic and religious groups that made up its population. With little education infrastructure and only a small number of high school and college graduates and skilled workers. Today, Singapore is a gleaming global hub of trade, finance and transportation. Its transformation "from third world to first" in one generation is one of Asia's great success stories (Yew, 2000). Singapore's economic freedom score is 89.7, making its economy the freest in the 2021 index. Its overall score has increased by 0.3 point, primarily because of an improvement in the score for government spending. Singapore is ranked first among 40 countries in the Asia-Pacific region, and its overall score is well above the regional and world averages. Singapore's economy has been ranked the freest in the world again this year for the second year in a row. Singapore remains the only country in the world that is considered economically free in every Index category, although its indicator scores for fiscal health and financial freedom just barely make it over the threshold into the highest category. Singapore is one of the world's most prosperous nations, with a businessfriendly regulatory environment and a very low unemployment rate.

Despite an active parliamentary opposition, it has been ruled by one party, the People's Action Party (PAP), for many decades. Prime Minister Lee Hsien Loong has led the government since 2004 and has suggested a leadership transition by 2022. Although certain civil liberties remain restricted, the PAP has championed economic liberalization and international trade. Services dominate the economy, but Singapore is also a major manufacturer of electronics and chemicals and operates one of the world's largest ports. Principal exports include integrated circuits, refined petroleum, and computers. Singapore has become one of the most important shipping centres in Asia and is often listed as one of the world's top three oil trading and refining hubs with a total crude oil refining capacity of 1.5 million barrels per day (bbl/d). In addition, Singapore is the market leader for highend floating production, storage and offloading (FPSOs) conversions and jack-up rigs, as well as the regional headquarters for most of the key players in the industry. Output from the oil and gas and petrochemical industries here in recent years was valued at US\$60 billion but it is expected to decrease due to fluctuating oil prices, unexpected diseases and global geopolitical issues. ${ }^{5}$

\section{Rationale}

The challenging task in the study of competitiveness is its empirical measurement and dichotomy of evidence that the competitiveness concept lacks a universally accepted definition, researchers has proposed a variety of approaches to estimate competitiveness in different literatures.

\footnotetext{
${ }^{5}$ https://www.trade.gov/energy-resource-guide-singapore-oil-and-gas.
} 
Competitiveness is found to be measured at different levels of economic analysis: mega-(global), macro-(nations, regions), meso-(economic sectors and industries) and micro-(firm's) level. A good example of the latter is the global competitiveness index (GCI) which comprises of such dimensions, as: institutions, infrastructure, macroeconomic environment, health and primary education, higher education and training, goods market efficiency, labour market efficiency, financial market development, technological readiness, market size, business sophistication, innovation. Competitiveness measures can be also classified into two categories: static (assessing competitiveness level at any point of time), and dynamic (assessing the changes in competitiveness over time). A further distinguishing characteristic of the competitiveness measures is their positive or normative nature. Positive indicators are based on observable evidence (forward loop) thus they reflect actual performance. Normative indicators (backward loop), on the contrary, involve value judgments. Closely related to this distinction is the one between ex post and ex ante measures.

An ex post competitiveness is given, for example, by measures of trade (e.g. market share) and current-account balance, both based on the past information, so with limited power to assess potential competitiveness. A potential (ex-ante) competitiveness demonstrates a capacity to compete and lies on indicators of technology, prices and costs. Good example is real (effective) exchange rate which can be calculated by using export prices, import prices and unit labour costs. Moreover, when assessing competitiveness, it is also important to determine if a measure represents the source or the outcome of competitiveness. For instance, low price, cost and high productivity are causes of a firm's strong competitiveness, while market share and trade balance represent the effects of the international competitiveness. The heterogeneity of competitiveness variables and measures (scenario) across the empirical studies may, regrettably, hinder the comparison of their findings. In view of the abundance of available measures used for assessing competitiveness, special caution is needed in choosing the right ones. It seems that in order to reflect the complexity of competitiveness, the most relevant approach is to use composite indicators capturing various components of this concept. Therefore, the following question represents our specific interest in this research field: What economic policy make Singapore world class economic destination relative to Nigeria? What links entrepreneurship and economic growth? What role the competiveness of Singapore add to the gross domestic product (GDP) compared to Nigeria. What factors have led to each country economic growth and to the differences between them? The following general objectives are:

i. To understand the overall contribution of innovation and entrepreneurship to the socioeconomic development of each country of study;

ii. To understand and compare the trajectories of competiveness ranking (nine); and

iii. The impacts of competitiveness of peace, human capital and infrastructure development.

\section{SPATIAL POLYSINGULARITY FRAMEWORK}

Porter outlined his conceptual framework of competitiveness first in the competitive advantage of nations, focusing on geographic location as a key determinant of company productivity (Porter, 1990, 1998). The competitive challenge for nations is to adapt state economic institutions and economic structures to produce a visible growth in the international scale (Bronisz et al., 2008). Stajano (2006) asserted that, the European Union's prosperity is based on its capacity to compete in the global market. In this alignment, competitiveness creates the basic conditions for sustainable development and growth, to the creation of new production activities and new jobs, and for a better quality of lsife (Kravchenko et al., 2013). Creativity, clustering and networking as a contribution to productive and efficient entrepreneurship, and knowledge is the key for sustainable growth (Vaz and Nijkamp, 2009). Regional Industry clusters, can be understood as an agglomeration of 
companies within one particular industry in a specific geographical area (Isaksen, 1997). In the regional context, network can be understood as all the relationships between local actors representing the quadruple helix interactions (Academia, Industry, Political Decision and Society) (Bjerregaard, 2010; Leydesdorff, 2011; Prainsack, 2012).

Globalized economy creates all the good things we like, but it also creates these highly complex issues such as climate change, inequality, environmental degradation, terrorism, global financial instability,multi-cultural integration or cyber security termed 'globalization polysingularity'. The defining feature of these issues is that, they are not 'isolated problems' but they are in a sense 'emergent features of the [very systems] through which we organize ourselves today (spatial). Competitiveness (wicked problems) today require a new skill set and more collaborative networked systems of organization to tackle (Figures 1). It is interesting to note that, in many ways these wicked problems can be understood to have derived from the standardized set of solutions (competiveness ranking) like the world economic forum. The terms system innovation and systems change have arisen in parallel to the idea of wicked problems as a new language is now entering the public sphere, seeing problems as interdependent", involving significant levels of "uncertainty" and "complex" termed polysingularity. In the face of a growing recognition to the systemic, interconnected, "interdependent and ever-evolving nature of these challenges, termed spatial. The solutions are systems-based approach to contexts specific situation quests for answers' called value, Figure 1.

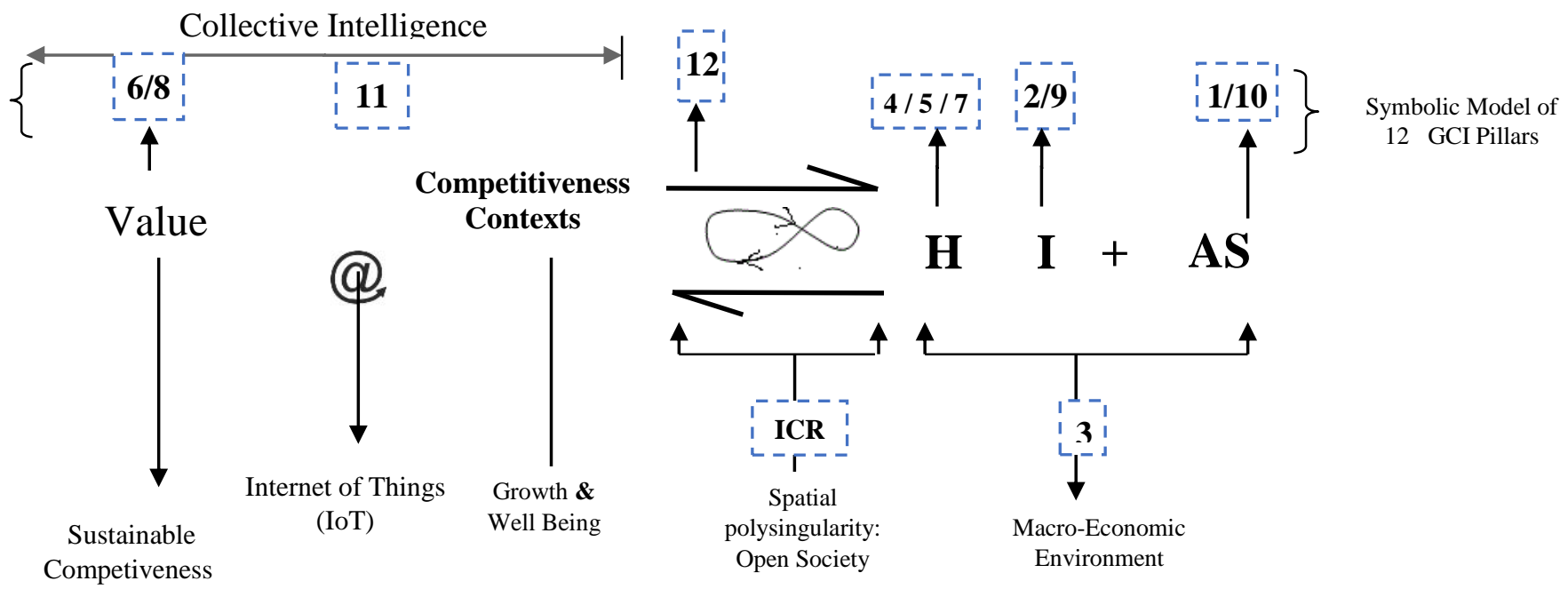

Figure 1 | Symbolic representation framework of global competitive indexes known as spatial polysingularity construct.

Spatial polysingularity is consistent with systems philosophy, systems thinking concerns an understanding of a system by examining the linkages and interactions between the elements that compose the entirety of the system where 'competitiveness' becomes object of value creation. Values are key in helping us draw boundaries (what's 'in' and what's 'out'?) and wicked problems solution are value-driven by interconnectedness (framework). The framework is the boundary between included and excluded stakeholders and inter-relationships (how do things connect with each other?). It represents values, and there is a two-way relationship between values and boundaries. The values that you bring into an arena of action will help drawing meaningful boundaries. Values are not general principles; they are linked to our personal, firms, cooperative, institutions, state, national and global goals. But some boundaries are already given by institutions, states actors and those boundaries constrain the type of values that may be expressed (perspectives, 
what are the different ways a situation can be understood?). The framework (Figure 1) illuminate competitiveness as case study, the narratives are: (1) exploring boundaries, understanding the inclusion, exclusion and marginalisation of stakeholders and the issues that concern them; (2) appreciating multiple perspectives, how and why stakeholders frame issues in different ways; even whether something is a system or not will depend on a person's particular perspective; (3) understanding relationships networks of interconnections within and across systems; (4) thinking in terms of systems themselves organised wholes with emergent properties that cannot be theories, nested systems.

Spatial polysingularity approach to competiveness (wicked problem) are:

(1) approaches for exploring value and boundary judgements about what should be included in or excluded from analysis, and marginalized as well;

(2) approaches for understanding complex causality, feedback, vicious and virtuous circles, and the possible consequences of intervention;

(3) approaches for developing viable and highly responsive organizations at multiple levels (global to local); and

(4) approaches for addressing conflict, exploring multiple perspectives, developing mutual understanding, and agreeing solutions that people are willing to implement (Figure 1).

Wicked problems never develop in a vacuum and are thus 'connected not only to other problems, but also to their results'- value streams (Table 1). Every problem interacts with other problems and is therefore part of a system of interrelated problems. ${ }^{6}$ Systemic problems inevitably need systemic approaches. A systemic view allows us to focus on our collective failure, and at the same time, on our collective potential to collaborate effectively. ${ }^{7}$ Wicked problems always materialise at the level of societies, beyond the grasp of individual organisations (like environmental issue, spatial be definition), Tables 1. At this level, different societal actors interact and create problems or are not able (or willing) to come up with solutions like climate change are polysingularity, and similar to taking stock of a problem from various angles is called triangulation. ${ }^{8}$ Considering the most important societal dimensions of a problem requires societal triangulation, in which the wickedness of the problem can be related to the behaviour and interests of the most important societal stakeholders that surround the issue. ${ }^{19}$ At societal level, identifiable groups of actors become stakeholders, have vested interests, adopt ideologies and create institutions that define the context in which problems become more or less wicked, Table 1.

\section{Collective Entrepreneurship" Context}

Defining competitiveness according to national economic development results in three main stages: (1) factor-driven, (2) efficiency-driven, and (3) innovation-driven; with two transitions between these stages (Acs et al., 2008; Amorós and Bosma, 2014; Porter, 1990; Schwab, 2013). Given the increasing competitiveness of the global market, regarding innovation and business sophistication, the advantages of cooperation networks lie in their ability to be flexible and to respond quickly to changing market conditions through highly personalized and differentiated products within a "collective entrepreneurship" context (Carney, 1998; Schwab, 2014; Yasuda and Iijima, 2005).

\footnotetext{
6. Ackoff. Redesigning the Future, p.21. Ackoff, R. L., (1981).

7. Conklin, Dialogue Mapping, p.37. Conklin, J.E. (2006).

${ }^{8}$ Van Tulder, Partnering Skills. This approach is a combination of institutional and welfare economics and very often applied in the partnering literature. See Van Tulder with Van der Zwart, International Business-Society Management for a basic elaboration and Waddock and others,
} 
The Global Competitiveness Report (GCR), published since 1979 by the World Economic Forum (WEF), is internationally renowned and brings together around 150 countries in a comparative analysis incorporating a wide range of variables leading to the calculation of the Global Competitiveness Index (GCI), including the pillars of "innovation" and "business sophistication" (Bergsteiner and Avery, 2011; Bronisz et al., 2008; Fendel and Frenkel, 2005; Ketels, 2006; Kravchenko et al., 2013; Schwab, 2013) where GCI model as a construct for as Spatial polysingularity construct (Figure 1).

Table 1. Spatial polysingularity construct symbolic representation model of Global Competitive Index (GCI) for the new paradigm for the study of competiveness measurement.

\begin{tabular}{|c|c|}
\hline Symbolic Representation & 12 Pillars of GCI \\
\hline Value & $\begin{array}{l}\text { Pillar 6: Goods market efficiency } \\
\text { Pillar 8: Financial market development }\end{array}$ \\
\hline Competiveness Context & $\begin{array}{l}\text { Specific Competiveness ranking typology /types based on } \\
\text { specific contexts (Appendices 1-7) }\end{array}$ \\
\hline & $\begin{array}{l}\text { Adaptive cycle } \\
\text { The solution that will favor perpetuation over innovation resulting } \\
\text { to resilience }\end{array}$ \\
\hline & $\begin{array}{l}\text { Pillar 9: Technology Readiness } \\
\text { Cloud technologies etc }\end{array}$ \\
\hline $\mathbf{H}$ - Human Capital & $\begin{array}{l}\text { Pillar 4: Health and primary education } \\
\text { Pillar 5: Higher education and training } \\
\text { Pillar 7: Labour market efficiency }\end{array}$ \\
\hline I - Infrastructure & $\begin{array}{l}\text { Pillar 2: Infrastructure } \\
\text { Automotive Telematics to the Cloud, etc }\end{array}$ \\
\hline A - Scenario Adaptive Cycle & $\begin{array}{l}\text { Countries/economies stage of development (stage 1-3) } \\
\text { and the transition to knowledge economy }\end{array}$ \\
\hline $\mathbf{S}-$ Stakeholder & $\begin{array}{l}\text { Pillar 1: Institutions } \\
\text { Pillar 10: Market size } \\
\text { Development of business model for communities of practice } \\
\text { using resilience innovation. }\end{array}$ \\
\hline $\begin{array}{l}\text { Spatial polysingularity Symbol for } \\
\text { Internet of Things (IoTs) }\end{array}$ & $\begin{array}{l}\text { Pillar 11: Business sophistication } \\
\text { Example: Google android ecosystem and platform for foresight } \\
\text { technology development innovation multiplier and platform } \\
\text { thinking (Figure 2) }\end{array}$ \\
\hline $\mathbf{H I}+\mathbf{A ~ S}$ & Pillar 3: Macroeconomic environment (Table 1) \\
\hline & $\begin{array}{l}\text { Pillar 12: Innovation } \\
\text { Open innovation paradigm for specific contexts }\end{array}$ \\
\hline
\end{tabular}

Knowledge-based entrepreneurial activity is generally assumed as the driving force behind economic growth, job creation and enhancing competitiveness (Guerrero et al., 2006; Guerrero and Urbano, 2010; Marques et al.,2010). On the other hand, national or regional competitiveness gains global acceptance as the key driver for sustaining prosperity and raising the welfare of citizens (Hoskisson et al., 2011; Schwab, 2013). Lawton Smith et al. (2013) asserted that, the entrepreneurial region concept comprises of three factors: (1) Entrepreneurs and entrepreneurial resources (skills, knowledge, infrastructures, finance and networks); (2) Entrepreneurial vision; and (3) Common vision from the potential regional stakeholders (including universities, companies and local policy makers) and ensuring the putting of ideas into practice within a coordinated perspective. Other authors argue that the regional success stems from the interrelationship between the three Triple Helix regional spaces: (1) Knowledge space; (2) Consensus space (State); and (3) Innovation space (Etzkowitz and Klofsten, 2005; Etzkowitz, 2008; Garnsey and Smith, 1998). The above lists parameters encapsulated in Table 1. 


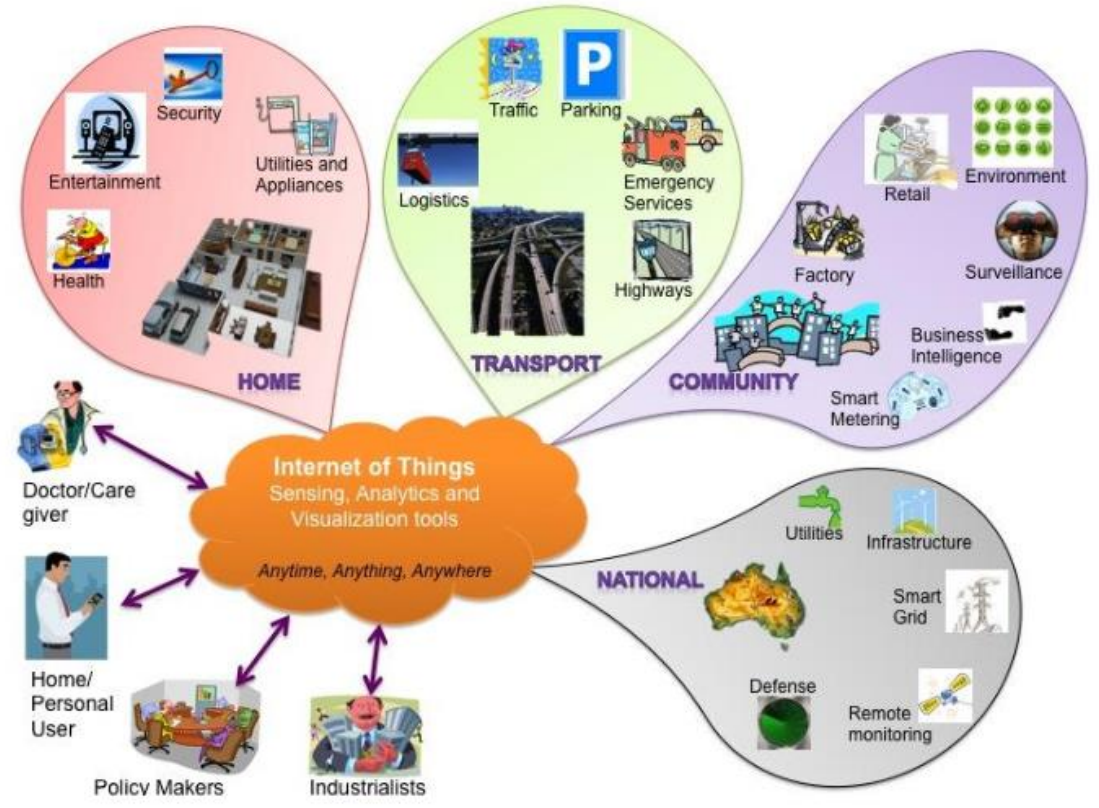

Figure 2 Internet of Things spatial polysingularity construct schematic showing the end users and application areas based on open data source of the determinants of competitiveness.

The increasing globalization of markets and the massification of competition associated with increasing technological complexity make innovation an important factor for firms, increasingly highlighting the importance of establishing cooperation networks (Boschma, 2004; Chesbrough, 2007; Lichtenthaler, 2010). Collaborative networks (Figure 2) drive an important contribution to increasing the competitiveness of economies and regions. This networking may involve the development of innovative projects, new technology, cost synergies or access to limited resources. This also results in benefits for regional competitiveness through the geographic proximity between firms and other regional / local actors (Awazu, 2006; Bigliardi and Galati, 2012; Deimel et al., 2010; Semlinger, 2008). Geographical proximity, the structures and relationships between the actors involved in the cluster associated with the trust of partners in the network may determine competitive success in the marketplace (Deimel et al., 2010; Lin et al., 2012).

The value chain of the automotive industry represents a major pillar of the modern economy and Europe is a key player. A case study for competitive environment, this industry takes on a fundamental role in terms of employment, production, outsourcing market and the level of investment, presenting major challenges and opportunities for the future (ZEW Economic Studies, 2004). Consequently, academic institutions such as entrepreneurial universities have tended to take on more pro-active approaches in close collaboration with industry to contribute to the development of new products and to improve the competitiveness of organizations and countries (Abramo et al., 2009; Comacchio et al., 2011; D'Este and Patel, 2007; Leydesdorff and Sun, 2009; Marques et al., 2006; Philbin, 2008; Rossi, 2013; Tee, 2005). The impacts of Academia-Industry (A-I) alliances now define an era of policy research, consulting and informal interactions that became ever more frequent as from the 1970s with the Massachusetts Institute of Technology (MIT) and later at Stanford University, both located in the USA, playing pioneering roles (Arza and López, 2011; Ojewale et al., 2001; Perkmann et al., 2013, 2011; Ranga et al., 2003; Van Looy et al., 2004). 


\section{Spatial Polysingularity | Value theory}

Spatial polysingularity approach to wicked problems are: (1) approaches for exploring value and boundary judgements about what should be included in or excluded from analysis, and marginalized as well; (2) approaches for understanding complex causality, feedback, vicious and virtuous circles, and the possible consequences of intervention; (3) approaches for developing viable and highly responsive organizations at multiple levels (global to local); (4) approaches for addressing conflict, exploring multiple perspectives, developing mutual understanding, and agreeing solutions that people are willing to implement. All economic systems sit upon a "Knowledge base". Value results from a total effort, rather than from 'one isolated step' in the process (Table 1 and Figure 1).New knowledge has overturned the world we know and shaken the pillars of power that hold it in place. Surveying the wreckage ready once more to create a new civilization, we stand, all together now, at ground zero because there is no framework for knowledge economy globally. Mapping quantitative and qualitative information from numerous functional areas: ideas, capital and talent as well as external sources, user-friendly, workfloworiented applications, multilingual and context-sensitive online help requires unification for a determinant of competitiveness within framework (Table 1).

\section{Fundamental}

Literature review established that, the value of individual qualities in terms of underlying competitiveness depends on the specific context in a location (like the Singapore and Nigeria case studies) driven by competitiveness drivers. Competitiveness drivers systemically interact (Table 1); the value of having a skilled workforce, for example, depends on factors like the availability of technology but also the openness of markets where the products these employees produce can be sold profitably. Improvements in competitiveness might thus depend on whether they relieve a 'bottleneck' in a specific context (Hausmann et al.,2005). Positive indicators are based on observable evidence (forward loop), thus they reflect actual performance. Normative indicators (backward loop), on the contrary, involve value judgments (Figure 1). Closely related to this distinction is the one between ex post and ex ante measures. An ex post competitiveness is given, for example, by measures of trade (e.g. market share) and current-account balance, both based on the past information, so with limited power to assess potential competitiveness. A potential (ex ante) competitiveness demonstrates a capacity to compete and lies on indicators of technology, prices and costs. Good example is real (effective) exchange rate which can be calculated by using export prices, import prices and unit labour costs.

1. Normative indicators (backward loop) with the symbol | $\left(\mathrm{ICR}^{\mathrm{a}}\right)$.

2. Positive indicators are based on observable evidence (forward loop), thus they reflect actual performance $\mid\left(\mathrm{ICR}^{\mathrm{b}}\right)$.

3. Collective Entrepreneurship Context $\mid \mathrm{ICR}^{\infty}$ infinite.

$\mathrm{ICR}^{\mathrm{a}}+\mathrm{ICR}^{\mathrm{b}}=\mathrm{ICR}^{\infty}$ Collective Entrepreneurship Context (infinite wealth creation).

This "leap" to a higher level of diversity, speed, and complexity requires a corresponding leap to higher, more sophisticated forms of integration. In turn, this demands radically higher levels of knowledge processing. Connectivity rather than disconnectedness; integration rather than disintegration, real-time simultaneity rather than sequential stages these are the assumptions that underlie the new production and services paradigm in the twenty first century; netclusters, (online plus offline industries in a location).This explain the growth of enabling technology infrastructure products, services and support companies in the world like Google, FaceBook etc. Given the increasing competitiveness of the global market, regarding innovation and business sophistication, 
the advantages of cooperation networks lie in their ability to be flexible and to respond quickly to changing market conditions through highly personalized and differentiated products within a "collective entrepreneurship" context and affirmed by scholars (Carney, 1998; Schwab, 2014; Yasuda and Iijima, 2005). Value results from a total effect, rather than from one isolated step in the process with IoT application development (Figure 2). The value stream created by spatial polysingularity construct are:

Demand value | The more people who can access information (or an application), the more valuable it is.

Information value | An IT infrastructure value is a result of the information it makes accessible, the more, the better. But information has to be timely, useful, accurate and relevant.

Asset Value | This goes beyond the value of people and machines. It includes hidden assets such machines. It includes hidden asset such people competence, work processing, trademarks and organizational structure that increase the corporate parent's market value.

Monetary value | Performance is a measurement of value; but an IT asset must still be convertible into money. Companies must consider the maintenance costs of current technology assets before investing further in systems and tools.

Online value | Similar to demand value, the online accessibility of IT assets adds to their value. Perceived value (also known as needs) | A customer's appreciation of the inherent worth quantified to every customer. Potential value can also come from benefits that are difficult to measure or that can't be immediately realized, such as future strategic opportunities.

Delivery value | Anything that improves the dependability of IT assets online delivery, effective resource management, predictability adds to their value.

Total value $\mid$ The sum of all value components both real and perceived.

Capture value: Market innovation, looking for new ways to make money rather than for new ways to make digital products and services.

Value creation | It is the challenge of finding a balance between a culture that promotes innovation and one that builds a sustainable business. This will creates the backbone of the new economy, with business-model powered by Internet of Things (IoTs) Figure 1.

\section{METHODOLOGY}

Competitiveness being explained by innovation and business sophistication, taking into account the association between the corresponding stages of economic development where entrepreneurship and competitiveness are nevertheless interconnected. The framework, consider competitiveness the measure of socio-economic development within the context of different geographies like Singapore and Nigeria case studies (Acs and Amorós, 2008; Amorós and Bosma, 2014; Bosma and Schutjens, 2011; Reynolds et al., 2005; Schwab, 2014) and apply methodology in economics and management in the analysis of how economists construct knowledge (Johnson, 1996). Both forms of deductive and inductive reasoning are considered logical processes and applicable in the conducting of research (Goel and Dolan, 2004; Overmars et al., 2007; Sivertsen, 2005). The competitiveness of the country depends on the competitiveness of national companies in both domestic and foreign markets. In the digital era, the country's competitiveness is determined by long-term factors: the application of innovation and global integration. World economic forum, 2018 introduces the new Global Competitiveness Index 4.0 assesses the factors determining the competitiveness of the country, which is the most important factor contributing to the long-term improvement of living standards. This provides the most complete analysis of various factors determining the competitiveness of the economy, as well as the assessment of the ICTs role and the level of digitalization in the context of global competitiveness (modelled in Figure 1). 
The Global Competitiveness Index analyses performance of countries on 12 pillars: institutions, infrastructure, macroeconomic environment, health and primary education, higher education and training, goods market efficiency, labour market efficiency, financial market development, technological readiness, market size, business sophistication and innovation. The pillars are grouped into three categories (sub-indices) in accordance with the three main stages of development: basic requirements, efficiency enhancers and factors of innovation and sophistication. The sub-indices are assigned different weights when calculating the total index. They depend on the stage of development of each economy which is expressed in terms of GDP per capita and the share of mineral exports. The empirical analysis was quantitative approach of competitiveness measurement/estimation known as integral competitiveness reports (ICR) with nine Global Reports on competiveness as case studies. Case study analysis is a methodology that allows researchers to focus on a specific concrete reality, leading to a better and deeper understanding of the facts (Baxter and Chua, 2003; Corcoran et al., 2004; Singh et al., 2014; Tranfield et al., 2003; Yin, 2014); offering rich descriptions of micro-level mechanisms and processes and thus facilitating the induction of quantitative standards for future research (Singh et al., 2014).

Case study analyses are a methodology that enables researchers to conduct their research in a sustained and focused way (Corcoran et al., 2004) and allow into a concrete reality, aiding a better and deeper understanding of the facts, based on the construction of interpretive theory (Baxter and Chua, 2003) with Singapore and Nigeria as case studies. Entrepreneurial initiatives and exports have a positive impact on national competitiveness increasing both productivity and the numbers of new firms (Hessels and Stel, 2009; Guerrero et al., 2006). According to a broad range of key players in society, including policymakers, academics, entrepreneurs as well as the general population, entrepreneurship holds an important impact on economic development and social welfare (Amorós and Bosma, 2014). Entrepreneurship and competitiveness are closely linked (Cuckovic and Bartlett, 2007; Huggins and Williams, 2011; Lawton Smith and Bagchi-Sen, 2012; Nordqvist and Melin, 2010). The creativity-entrepreneurship nexus reinforces the approach to entrepreneurship by opportunity (Audretsch and Belitski, 2013).

\section{How to measure competitiveness?}

The measurement of competitiveness should potentially cover:

i. Outcome indicators that capture the final objectives of policy;

ii. Intermediate indicators that provide insights into competitiveness, and track how underling competitiveness drives outcomes;

iii. Fundamental factors of competitiveness that structurally drive outcomes and are core levers for policy interventions that can have a sustainable impact; and

iv. Control indicators that capture potential imbalances that have the potential to create high short-term costs even if they don't drive outcomes in the long run.

A robust competitiveness analysis should focus on the prior but empirically separating the two is bound with difficulties. Also, for many indicators of fundamental competitiveness the interpretation of absolute values is hard. It requires a benchmark in terms of changes over time and more importantly peer or rival locations, like the GCR. The research on competitiveness also reveals a number of additional challenges that are related to the nature of how different factors influence the potential productivity of an economy. Competitiveness drivers systemically interact; the value of having a skilled workforce, for example, depends on factors like the availability of technology but also the openness of markets where the products these employees produce can be sold profitably. 
Improvements in competitiveness might thus depend on whether they relieve a 'bottleneck' in a specific context (Hausmann et al., 2005) and see Figure 1 and Table 1. Second, a related view is that the value of specific competitiveness drivers depends on a location's overall stage of economic development and at a narrower level the strategic positioning of the location in the markets in the global economy. The idea of countries' requiring different qualities as they reach higher levels of economic development is not new; as affirmed by Porter's competitiveness advantage of nations (Porter, 1990). The view that there are not only these generic patterns but that, locations can also choose more specific strategic positions within these overall categories is more recent (Valdaliso/Wilson, 2015). Third, the discussion of individual factors that shape fundamental competitiveness has already indicated that their role in competitiveness outcomes but also the process to change them through policy action differs significantly:

i. Macroeconomic policies have a high short-term impact on economic outcome but there longterm impact on prosperity levels is limited powered by government policies.

ii. Social infrastructure and political institutions change generally only slowly over time, but then have an important impact on long-term prosperity levels. Government has influence on these factors but the process is complex, involves others.

iii. Microeconomic competitiveness includes a range of factors with different properties: some are controlled by government and can be changed quickly, while others are the outcome of more long-term process involving many actors and decision makers.

Overall, the measure of competitiveness based on a simple aggregation of individual qualities can be highly misleading and detailed interactions between competitiveness factors are too complex to capture them in a model that would represent the underlying system dynamics. In practical applications, differentiating between cross-country rankings and country-specific analyses illuminate value streams, Figure 1 and Table 1 respectively.

\section{MATERIALS}

\section{Determinants of Competitiveness}

A great deal of the empirical research refers to the determinants of competitiveness at the enterprise level, probably due to the conviction that firms, not individual nations, compete in international markets, as also Porter (1990) argues. Hollensen (2010), asserted national circumstances create an environment in which businesses can gain international competitive advantages but it depends on the firm whether it grabs the opportunity to gain competitive advantage or not. McGahan (1999) suggests that external factors are more or less uniform for all competing companies and it is a firm's characteristics and action that determine its profitability. Based on the literature reviews, authors identified micro- and macro-economic sources of firm's competitiveness. Microeconomic factors, having a direct impact on company competitiveness include: sophistication of firm's operations and strategy, quantity and quality of production factors, technology and innovations as well as supporting or related industries and clusters.Macroeconomic environment (monetary and fiscal policy, the rule of law and the quality of social and political institutions) sets general conditions creating opportunities for higher corporate competitiveness.

\section{Competitiveness Rankings}

Competitiveness rankings assemble data across a range of locations to compare their performance like GCR by world economic forum. They are often generated by international institutions or nongovernment organizations with a global perspective. Rankings are often criticized by academic researchers (Lall, 2001). One challenge is that they emphasize a zero-sum nature of competitiveness; one country's improvement is another country's loss. 
This neglects the important benefits of another country's productivity on prosperity for all that international trade economics have clearly revealed. Another, more technical issue is the aggregation of individual indicators into a single synthetic indicator (OECD, 2008).The weights and specific functions for this aggregation are often viewed to stand on weak methodological foundations. There is also the mapping of an essentially continuous variable, i.e competitiveness or 'underlying productivity potential' into a discrete variable that imposes similar distances between ranks. This can be highly misleading, creating discussion about rank changes among countries of similar competitiveness that have no meaningful implication while understating the large gaps between countries at different stages of competitiveness upgrading. Rankings are, however, very powerful tools for communication and driving policy action. Rankings map the complexity of many factors interacting in many ways into a simple indicator that can be easily understood. A number of countries have set goals in terms of improvements in specific rankings, and defined reform strategies to achieve them with positive policy dynamics such rankings can at least potentially trigger.

\section{Comprehensive competitiveness rankings}

GCI competitiveness rankings globally provide a comprehensive assessment of overall competitiveness for a large number of countries with the crux of data generation and aggregation and internet of Things will optimize data collection (Figure 2). Global Competitiveness Report (GCR) uses a mix of hard data and country-level surveys conducted by national partner organizations as the basis of its ranking. It organizes the data on individual indicators through integral competitiveness ranking (ICR). It explicitly aims to capture the underlying drivers of productivity differences but also mentions an ambition to help reveal drivers of growth. The aggregation of data into country level scores and then an overall ranking is done through a weighting system informed by experts' view of the relevant research. The integral competitiveness (spatial; polysingularity construct) extended the scope of indicators to capture more of the 'complex' factors related to individual and institutional capacity. It also analyses the data more within the context of specific 'peer groups' of countries with similar profiles. There are also rankings like Transparency International's Corruption Perception Index and the Heritage Foundation's Index of Economic Freedom that cover specific issues, often by analysing data collected from other sources that was not included this expose this paper.

Many studies identify areas in which a country's lacks the most given its overall level of competitiveness, hoping that these are the areas where changes will unlock the highest returns. Countries can benefited from a successful positioning around key competitive advantages factdriven analysis of integral competitiveness. Competitiveness assessments aim to inform the design of effective policies to increase the level of prosperity a location (Singapore and Nigeria) can reach called 'integral competitiveness fundamentals' that can impact developed as a framework to capture the traditional and new aspects of competitiveness called 'competitive set.' This is a model that helps to interpret the data that is being collected in different dimensions of competitiveness. Given the broad definition of competitiveness that recognizes the role and influence of a wide range of policy areas, Also, significantly enhanced if systematic linkages are created between its work and assessments and related key policy planning efforts, like focusing on enhancing the growth of domestic entrepreneurship, and more long-term ambitions, like the value proposition comprehensive enough to capture likely policy priorities and a useful trigger to engage in a dialogue of the country's broader policy process. Lists of integral competitiveness ranking (ICR):

\footnotetext{
i. Global Manufacturing Competitiveness Index: Country rankings | 2020

ii. Competitive Industrial Performance Report 2020

iii. The Global Competitiveness Report 2020
} 
iv. Hot spots 2025 Benchmarking the future competitiveness of cities

v. The Global Sustainable Competitiveness Index 2020

vi. The Global Innovation Index (GII) 2020

vii. The Global Talent Competitiveness Index 2020

viii. Global labour resilience index 2020

ix. Global Peace Index 2020.

\section{CASE STUDIES}

\section{Country - specific reviews}

The ultimate objective of competitiveness assessments in policy practice is the development of recommendations for government action. Competitiveness rankings are an important input into this process but do by themselves not generate the specific conclusions for policy makers and the aim is fill this gap by drawing on a wide range of existing data for the location in question but also often in comparison to other locations like Singapore and Nigeria case studies. It is relatively straightforward to compare a county's performance on a specific policy area with its peers and make recommendations for improvement. A range of international organizations provide country-specific assessments that cover issues related to competitiveness. The purpose of these assessments is in some cases directly related to the activities of these organizations, helping to guide them and supporting the evaluation of their effectiveness. A final example of country-specific assessments as part of a process covering many countries is the World Bank's new Systematic Country Diagnostics, a key step in the Bank's activities to design country-specific partnership agreements and action programs. ${ }^{9}$ The scope of policy areas under review is large, driven by the Bank's dual goal of ending extreme poverty and promoting shared prosperity Specific national competitiveness reports have also been written for countries like Estonia (Meriküll et al., 2014), Latvia (Cunska et al., 2013), and Sweden (Regeringskansliet, 2015). These reports differ significantly in their scope and level of ambition. Some provide not much more than a summary of rankings for a specific country from the international reports available.

\section{Implications}

The significant number of country rankings and country-specific reviews of competitiveness are an indication of a broader shift towards more evidence-based policy making (Davies, 2012). While practice does not always match the rhetoric, there seems to be a general recognition that policy advice needs to be informed by data on the specific situation a country is facing rather than just applying generic recipes (Rodrik, 2007). A key challenge is how to translate information about specific strengths and weaknesses across the many factors that drive competitiveness into action recommendations. The question is where the line should be drawn between data analysis and the development of policy-related recommendations. On the one hand, pure analysis that does not make the step towards identifying priority issues leaves policy makers with little actionable insights. The consequence, policy recommendations that are not derived in a process that intimately involves the key stakeholders and decision makers hardly ever lead to action, there is a need for framework construct (Figure 1).

\section{RESULTS}

The main reason of the multiplicity of definitions of national competitiveness is the complexity of the term; its composite character; moreover, the system concept of the category itself.

\footnotetext{
${ }^{9}$ http://www.worldbank.org/en/projects-operations/country-strategies\#3
} 
Competitiveness is a complex multidimensional concept. It reflects the favourable position of the national economy, mainly in the field of international trade and, at the same time, its ability to strengthen this position. On the other hand, the competitiveness of the national economy is a concentrated expression of economic, scientific, technological, organizational, managerial, marketing and other capabilities that are implemented in goods and services, successfully insuring their competing opposite foreign goods and services at the domestic and foreign markets. The national competitiveness is an ability of a state to achieve high rates of economic growth, ensure a steady increase in real wages, promotion of domestic firms on the world market represented by high-performance clusters that improve the quality of products and services that enable the future. This competitive ability to adapt to changes occurring in the global market is based on following economic factors such as investment volume, innovation ability, manufacturing facilities, and others. Where, their performance must be combined with political and social factors that also affect the functioning of the national economy in the world market (Antoniuk, 2004). Several well-established studies measure competitiveness at the country level like the Global

Competitiveness Index (GCI), published annually by the World Economic Forum (Schwab, 2009; Schwab and Porter, 2007), and the World Competitiveness Yearbook by the Institute for Management Development (IMD, 2008) are the most influential and best-known indices. GCI Index to a large extent adopts and builds upon the methodology developed by the WEF for the Global Competitiveness Index-GCI (Schwab, 2009).

Competition power of a country can simply be defined as the ability to compete relative to its rivals using The Global Competitiveness Index (GCI) 12 pillars (WEF, GCR, 2011); ability to produce goods and services that meet the test of international competition while our citizens enjoy a standard of living that is both rising and sustainable WEF [Schwab, Sala-i-Mart 2013]; set of institutions, policies, and factors that determine the level of productivity of a country World Economic Forum, WEF (1996) and ability of a country to achieve sustained high rates of growth in GDP per capita, encapsulate in frameworks (Figure 1). The Global Competitiveness Report 2020 which maps the competitiveness of 141 economies through 103 indicators organized into 12 pillars. ${ }^{10}$ Covering 141 economies, the Global Competitiveness Index 4.0 measures national competitiveness - defined as the set of institutions, policies and factors that determine the level of productivity reported Singapore Ranked (1) and Score (84.8) while Nigeria Ranked (116) and Score (48.3).

\section{Hot spots 2025 benchmarking the future competitiveness of cities}

Cities of all sizes can be competitive. The top ten most competitive cities in 2025 range from the world's biggest (Tokyo, with an estimated population of $37 \mathrm{~m}$ ) to some of the smallest (Zurich, estimated population $1.4 \mathrm{~m}$ ). Indeed, there is no major correlation between a city's size and its competitiveness ranking in the Index. Densely populated small city states such as Singapore ${ }^{11}\left(3^{\text {rd }}\right)$ and Hong Kong $\left(4^{\text {th }}\right)$ will be among the most competitive places in 2025 , along with Sydney $\left(6^{\text {th }}\right)$ and Stockholm $\left(8^{\text {th }}\right)$, which are spread out over a large geographical area particularly poorly, with South Africa providing the only decent contenders, such as Johannesburg $\left(66^{\text {th }}\right)$, Cape Town $\left(77^{\text {th }}\right)$ and Durban $\left(95^{\text {th }}\right)$. In northern Africa, Cairo $\left(106^{\text {th }}\right)$ benefits from the economic power derived from its sheer size in 2025 Lagos (119) score 29 and Singapore (3) Score 71.2.

\footnotetext{
${ }^{10} \mathrm{https}: / / \mathrm{www}$.weforum.org/reports/the-global-competitiveness-report-2020

11 https://www.citigroup.com/citi/citiforcities/pdfs/hotspots2025.pdf

12 https://www.csrwire.com/press_releases/708956-global-sustainable-competitiveness-index-2020
} 


\section{The Global Sustainable Competitiveness Index 2020}

The GSCI is based on 127 quantitative indicators grouped in the five (5) pillars of national competitiveness. ${ }^{12}$ It is based both on the latest available performance data as well as the recent development of the indicators. Based on purely quantitative indicators. Taking into account 127 indicators derived from recognised global data sources (World Bank, various UN agencies, IMF). Grouped into the pillars of development: natural capital, resource efficiency, social capital and intellectual and innovation capital, governance performance. Evaluating latest available data points and trends over time to better reflect future development. Singapore 44th Score 50.3\%. Nigeria $149^{\text {th }}$ Score $40.9 \%$.

\section{Global Innovation Index 2020}

Global Innovation Index (GII) ${ }^{13}$ is to provide insightful data on innovation and, in turn, to assist policymakers in evaluating their innovation performance and making informed innovation policy decisions. Singapore 56.61 (score) 8 (ranked).Nigeria 20.13 (score) 117 (ranked).

\section{The Global Talent Competitiveness Index 2020}

The Global Talent Competitiveness Index (GTCI) ${ }^{14}$ covers national and organisational parameters and generates insights to inspire action. Based on feedback and further analyses following the release of previous editions of the report, this year's index includes 70 variables. It covers 132 national economies, across all groups of income and levels of development. The GTCI is a composite index, relying on a simple but robust Input-Output model, composed of six pillars (four on the Input side and two on the Output side), and has (1) four pillars on the input side - Enable, Attract, Grow and Retain-focusing on actions for policymakers and business leaders, and (2) two output pillars, benchmarking national performances in Technical/Vocational and Global Knowledge skills, respectively. Singapore 78.48 (score) 3 (ranked) Nigeria.

\section{Global Labour Resilience Index 2020}

Global Labour Resilience Index 2020 (GLRI) ${ }^{15} 2020$ ranking Singapore 2 (rank) 97 (score) Nigeria 129 (rank) 27 (score).

\section{Global Peace Index 2020}

Global Peace Index ${ }^{16} 2020$ Singapore 7 (ranked) Score (1.321). Nigeria 147 (ranked) Score (2.865) Total: 163.

\section{DISCUSSIONS}

The ICR indexes does not apply a one-size-fits-all approach to competitiveness. On the contrary, it assumes that the focus in less developed economies should be different than in intermediate or highly developed economies. Whereas less developed economies need to ensure that their basic transport infrastructure, basic education and health care services are of a good quality, highly developed regions should be more concerned about their business sophistication and their use of technology and innovation. Globalization of competition on the supply side, occurring in integration of planning and cooperation of economic in the global market, in order to stand against other global competitors. Watching a steady supply growth caused by global suppliers, who are working on the base of international labour division.

\footnotetext{
13 https://www.wipo.int/global_innovation_index/en/2020/

14 https://gtcistudy.com/

15 https://www.whiteshieldpartners.com/files/glri_2020.pdf

16 https://www.visionofhumanity.org/wp-content/uploads/2020/10/GPI_2020_web.pdf
} 
The acquisition and maintenance of competition globalization and competitive advantage is determined by homogenisation of demand. The number of globally operating customers and sales agents is constantly increasing (Melnikas,1998; Glebocka,1997). The market polarization occurring due to the economic globalization1 process is particular that one group of consumers prefer highquality and high-value commodities more often, while the other - low cost, ignoring the mediumquality goods. Sustainable competitive advantage is a key concept in strategy practice and research, because of the intended result of sustainable competitive advantage is persistent superior economic performance (Baaij et al., 2004). Sustainability has restrictions on the implementation of its practices, apart from government decisions, there are other restrains on sustainability approach, in this field-despite its multidisciplinary character-cannot replace other non-sustainable initiatives, because the relation involving demand and supply goes beyond any perspective of sustainability, due to the modus operandi of societies as a whole (Novais et al., 2012).Since sustainability issues should be analysed and solved on the system levels where they develop and manifest themselves. Bartelmus (2003) conclude that economic sustainability keeps the total value of produced and nonproduced, natural capital intact-allowing for the consumption of fixed and natural capital, and ecological sustainability, which aims at 'dematerialization' of economic activity; the objective is to reduce material throughput through the economy and its pressure on nature's carrying capacities.

Singapore topped both IMD's World Competitiveness 2020 and World Economic Forum (WEF)'s Global Competitiveness ${ }^{17}$ rankings in 2019. Singapore ranked top three across numerous domains including the quality of its institutions, infrastructure, labour market, openness to trade and financial system (2019 WEF Global Competitiveness rankings). Singapore ranked $1^{\text {st }}$ in the IMD Smart City Index $^{18}$ and 2 nd globally in digital competitiveness ${ }^{19}$ in 2019. Singapore's digital friendly environment, high quality infrastructure, and efforts in adopting technologies in an efficient way to improve the quality of life for Singaporeans were key drivers. On innovation performance, Singapore ranked top in Asia in the Global Innovation Index 2019. Among global economies, Singapore was assessed to be the most innovative in terms of the quality of innovation input, which include business environment, quality of tertiary education, human capital and research, and government efficiency. ${ }^{20}$ Singapore is located at the heart of Southeast Asia and provides excellent global connectivity to serve the fast-growing markets of the Asia-Pacific region and beyond. Singapore has forged an extensive network of over 20 implemented Free Trade Agreements (FTAs) -providing privileged access to the markets of partner countries. In addition, we have signed over 80 Avoidance of Double Taxation Agreements (DTAs). These work to the advantage of any financial institution using Singapore as its regional or global hub.Singapore is also building linkages, including through Bilateral Investment. Treaties and FinTech Cooperation Agreements, ${ }^{21}$ with countries further afield including in the Middle East, Africa and South America, given the growing trade and investment interests in emerging economies. For the $6^{\text {th }}$ consecutive year, Singapore ranked $1^{\text {st }}$ in Asia-Pacific, and $3^{\text {rd }}$ worldwide in the 2020 INSEAD Global Talent Competitiveness Index. ${ }^{22}$ Singapore ranked $1^{\text {st }}$ in its ability to enable and attract talent. Workers here also emerged top in global knowledge skills, i.e. in professional, managerial or leadership roles that require creativity and problem solving (Appendix 4).

\footnotetext{
17 World Economic Forum (WEF)'s Global Competitiveness Report (2019)

18. IMD Smart City Index (2019)

19. IMD World Digital Competitiveness Ranking (2019)

20. Global Innovation Index (2019)

21 MAS FinTech Cooperation Agreements

22. INSEAD Global Talent Competitiveness Index (2022).
} 
Singapore ranked highly in all five areas of competitiveness: business environment, human capital, infrastructure, financial sector development, and reputational metrics. In its 2019 Financial Sector Assessment Programme (FSAP) for Singapore, the International Monetary Fund (IMF) reaffirmed Singapore's financial sector oversight to be "among the best globally" and noted that MAS has struck a good balance in fostering financial innovation while strengthening regulatory oversight since its last FSAP ${ }^{23}$ review in 2013. Last year's report included the first time-series analysis of GTCI data in order to assess how talent competitiveness is changing globally. Two main conclusions were drawn. First, that talent inequalities appear to be broadening, as reflected by a widening gap between the talent champions and the rest. Second, that more talent competitive countries are, in general, more stable in their performances than countries lower down the rankings. Both these takeaways remain just as valid in this year's updated analysis. GTCI model appears to be a particularly promising way to identify trends as well as to draw additional policy conclusions about how the various components of talent competitiveness can be better fostered. ${ }^{14}$

\section{Significance of Indexes}

\section{Global Peace Index 2020}

The economic impact of violence on the global economy in 2019 was $\$ 14.5$ trillion in purchasing power parity (PPP) terms. This figure is equivalent to 10.6 per cent of the world's economic activity (gross world product) or $\$ 1,909$ per person. The economic impact of violence improved by 0.2 per cent from 2018 to 2019 . The biggest improvement was in armed conflict, which decreased by 29 per cent to $\$ 521$ billion, owing to a fall in the intensity of conflict in the Middle-East and North Africa. There was also a substantial reduction in the economic impact of terrorism, which fell by 48 per cent from 2018 to 2019. The 2020 GPI reveals a world in which the tensions, conflicts, and crises that emerged in the past decade remain unresolved, but some progress has been made towards achieving peace Global Peace Index 2020 (Page 3). The greater the economic complexity of countries, regions and cities the greater the importance of investment in technology, innovation, and higher education in driving labour market resilience. Policies relating to innovation and technology have the strongest correlation with labour market resilience for high income OECD countries. Given the widespread fears of technological unemployment it is interesting to note that investment in technology is so strongly associated with positive labour market outcomes in higher income countries. Three out of the top five countries with the highest level of robots installed per employee are in the GLRI top ten most resilient labour markets in the world and also have among the lowest levels of unemployment: Singapore, Germany and Sweden. ${ }^{25}$ Greater labour market resilience and lower unemployment levels associated with higher robot adoption rates reinforces the notion that robots can be effectively used to augment human productivity by focusing on more repetitive tasks and addressing labour shortages rather than simply replacing humans in the workforce.

\section{Singapore}

\section{Alignment of the education system to economic development goals}

The strong link between education and economic development in Singapore has kept investment in education a central priority, made education policies highly pragmatic, led to high-quality mathematics and science and also to world-class vocational/technical education- an area where most countries fail. It has also kept education dynamic, expecting to change as conditions change rather than being mired in the past. While the tightness of the link may not be possible in less

\footnotetext{
23 MAS' Media Release, 16 July 2019, "IMF Reaffirms Singapore's Financial Sector Oversight as 'Among the Best Globally.',

25 https://ifr.org/ifr-press-releases/news/record-2.7-million-robots-work-in-factories-around-the-globe
} 
planned economies, bringing together economic and education policy makers, business and education leaders to continually assess changes in economic conditions and how education and economic development could better work together would strengthen both (Appendix 3).

\section{Strong central capacity and authority to act}

The ministry of Education in Singapore is staffed by knowledgeable, pragmatic individuals, trained at some of the best universities in the world. They function in a culture of continuous improvement, constantly assessing what is and isn't working using both data and practitioner experience. They respect and are respected by professionals in the schools. Whilst countries vary in whether the locus of authority is at the national state/province or local level, whoever is charged with developing strategy and holding authority would do well to emulate the competence and capacity of the Singapore ministry of education (Table 2, Appendix 1).

\section{Meritocratic values}

Underpinning the whole Singaporean system is the belief for students of all ethnic backgrounds and all ranges of ability - that education is the route to advancement and that hard work and effort pay off. The government has developed a wide range of educational and social policies to advance this goal, with early intervention and multiple pathways to education and career. The success of the government's economic and educational policies has brought about immense social mobility that has created a shared sense of national mission and made cultural support for education a nearuniversal value. Lee Kuan Yew's greatest fear was that his little country would fall prey to the kinds of ethnic and religious rivalries that have thwarted the development of so many other societies. He realised that what happens in the schools could be one of the most important antidotes to this threat. So the schools became a theatre in which the country would do everything possible to give all students the skills and knowledge needed to succeed, independent of their socioeconomic status. Singapore makes sure that every school has a fair share of the best teachers, and assigns their best teachers to the students who are struggling. They have been especially successful at training their teachers to diagnose student challenges and figure out how to address those challenges successfully. The belief that achieving high standards is a function of effort is stoutly embraced in Singapore and extends to the great emphasis put on raising the quality of the educators. Singapore is exemplary in the professional way that its teachers view their responsibilities. All these elements of policy have combined to produce a remarkably wellperforming education system (Appendix 4).

\section{Adaptation of proven practices from abroad}

The design of Singapore's education system owes a lot to lessons from other parts of the world. Focused and universal use of international benchmarking and, more recently, significant funds for research, have enabled Singapore to move up the value chain and foster a culture in which it never stands still (Appendix 2). This system recognises the rapidity of change around the world and has the capacity and inclination to learn and adapt. Singapore fosters a global outlook for everyone teachers, principals, and students - who are expected to have "global awareness and cross-cultural skills" and to be "future-ready". In the words of Tan Chorh Chuan, President of the National University of Singapore, Singaporeans must be ready to "scale new heights in a changed world" and see Appendix 1.

\section{Nigeria}

The structure of the Nigerian economy is typical of an underdeveloped country. Over half of the gross domestic product (GDP) is accounted for by the primary sector with agriculture continuing to play an important role. The Nigerian economy now accounts for 35\% of Sub-Saharan Africa's GDP (IMF, 2015). Despite the size of the economy and its recent growth progress the Nigerian 
economy continues to face significant competitiveness challenges. The Nigerian economy is characterized by structural challenges that limit its ability to sustain growth, create jobs and achieve real poverty reduction. The economy is highly dependent on a single commodity for economic activities, fiscal revenues and foreign exchange oil and must import raw materials and intermediate goods to sustain the manufacturing sector (Appendix 1). The economy is also skewed towards consumption rather than investment, with gross domestic investment (GDI) to GDP ratio hovering at 13-14 per cent. Businesses in Nigeria cite poor infrastructure - the lack of reliable power supply and transportation - as a critical challenge. ${ }^{26}$ The total value of Nigeria's infrastructure stock represents only 35 per cent of GDP, compared to 45-90 per cent in BRICS countries (Appendix 5). Corruption and security issues -terrorism, insurgency, piracy, oil theft -are of serious concern and constitute major barriers to economic growth and social development. Poverty and social exclusion rates are high. About 61 per cent of the population lives on USD\$1 or less a day. Human development indicators paint a bleak picture of Nigeria's health and education systems. The country has the fourth-highest infant mortality rate in the world, and nearly 55 per cent of this is attributable to malnutrition (Appendix 7). Nigeria's primary school net enrolment rate is 54 per cent and 10 million children of school age do not attend school. Nigeria has the potential to become a major player in the global economy by virtue of its human and natural resource endowments. However, this potential has remained relatively untapped over the years.

After a shift from agriculture to crude oil and gas in the late 1960s, Nigeria's growth has continued to be driven by consumption and high oil prices. Previous economic policies left the country illprepared for the recent collapse of crude oil prices and production. The structure of the economy remains highly import dependent, consumption driven and undiversified. Oil accounts for more than 95 per cent of exports and foreign exchange earnings while the manufacturing sector accounts for less than one percent of total exports. General economic performance was also seriously undermined by deplorable infrastructure, corruption and mismanagement of public finances. Decades of consumption and high oil price-driven growth led to an economy with a positive but jobless growth trajectory. High levels of Inflation averaging about $28.94 \%$ per annum was recorded over the same period. A major challenge for the Nigerian economy, as this trend portrays, is its macroeconomic volatility as a result of external terms of trade shocks and very high reliance on oil export earnings. In a 2003, World Bank report cited in Okonjo-Iweala and Osafo-Kwaako (2007), Tables 3 - 4 (Appendix 5). Nigeria aspires to have a rapidly growing economy with diversified sources of growth, increased opportunities for its people, and a socially inclusive economy that reduces poverty and creates jobs for the millions of young people entering the labour market annually (Appendix 6). To achieve these objectives the Federal Government of Nigeria is determined to provide the leadership required to establish a well-governed society with stable macroeconomic conditions, and a dynamic, competitive environment that enables the private sector to thrive. The current administration recognizes that the economy is likely to remain on a path of steady and steep decline if nothing is done to change the trajectory. It is in this context that since inception in May 2015, Government has made several efforts aimed at tackling these challenges and changing the national economic trajectory in a fundamental way. The earliest action was the prioritization of three policy goals: tackling corruption, improving security and re-building the economy.

\footnotetext{
${ }^{26}$ Federal Republic of Nigeria Economic Recovery \& Growth Plan 2017-2020 Ministry Of Budget \& National Planning February, 2017 https://nigeriaembassygermany.org/mosaic/_M_userfiles/Economic-Recovery-Growth-Plan-2017-2020.pdf
} 


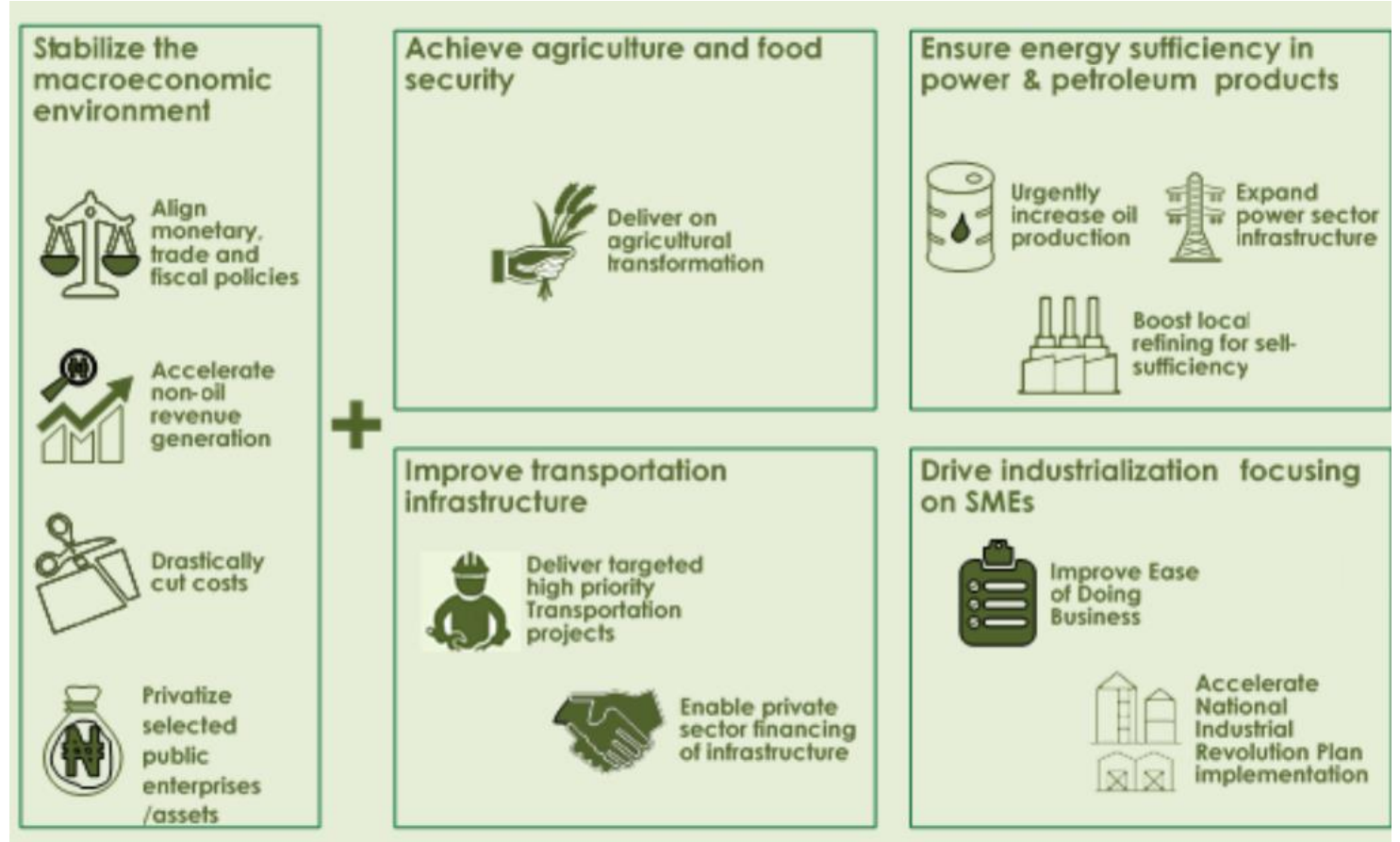

Figure 3 | ERGP's Top Execution Priorities. ${ }^{27}$

Consequently, the Strategic Implementation Plan (SIP) for the 2016 Budget of Change was developed as a short-term intervention for this purpose. Visible successes and achievements have been recorded. However, it is recognized that more needs to be done to propel the country towards sustainable accelerated development. The Economic Recovery and Growth Plan (ERGP), a Medium Term Plan for 2017-2020, builds on the SIP and has been developed for the purpose of restoring economic growth while leveraging the ingenuity and resilience of the Nigerian people -the nation's most priceless assets. It is also articulated with the understanding that the role of government in the $21^{\text {st }}$ century must evolve from that of being an omnibus provider of citizens' needs into a force for eliminating the bottlenecks that impede innovation and market-based solutions. The Plan also recognises the need to leverage Science, Technology and Innovation (STI) and build a knowledgebased economy. The ERGP is also consistent with the aspirations of the Sustainable Development Goals (SDGs), given that the initiatives address its three dimensions of economic, social and environmental sustainability issues (Tables 3-4, Appendix 5).

The ERGP was developed through a consultative process comprising retreats, seminars and round tables with a cross-section of Nigerians. It involved discussions within the Executive, with the National Assembly, the private sector, civil society groups, academia, and international development partners. These public engagements enabled frank and open discussions about the challenges and opportunities for the Nigerian economy in the immediate and medium term. The ERGP aims to restore sustained economic growth while promoting social inclusion and laying the foundations for long-term structural change. It will focus on providing macroeconomic stability, stimulating priority sectors and tackling critical constraints to long-term growth. There are three possible scenarios for the Nigerian economy going forward, each of which has different implications for the goals of early economic recovery, creating jobs and boosting inclusive and sustainable growth (Figure 3) :

\footnotetext{
27 Federal Republic of Nigeria Economic Recovery \& Growth Plan 2017-2020 Ministry of Budget \& National Planning February, 2017.

https://nigeriaembassygermany.org/mosaic/_M_userfiles/Economic-Recovery-Growth-Plan-2017-2020.pdf.
} 
1. Do nothing - The Federal Government undertakes no macroeconomic or structural reforms and continues to conduct business as usual in the hope that oil prices recover. Given the high direct and indirect effects of oil prices on the current economic structure and the fact that they are likely to remain low, the economy would continue to contract in the short term and growth would be close to zero by 2020. Net job growth would remain weak and unemployment would rise from an estimated 14.2 per cent at the end of 2016 to 31.3 per cent by 2020 . Poverty would remain high, increasing from the current rate of 61 per cent to $65-70$ per cent in 2020. Income per capita would decline as total GDP stays relatively flat while the population grows.

2. Introduce basic macroeconomic reforms - The Federal Government introduces some basic reforms to clarify the monetary policy stance and improve fiscal and external balances. It does not undertake structural reforms. This implies that the structure of the economy would remain largely dependent on the oil sector. The reforms would encourage a modest short-term recovery and real GDP growth of approximately 3.8 per cent by 2020. This scenario would create about 3 million jobs but unemployment/underemployment rates would increase to 25 per cent by 2020 as the pace of job creation would not be high enough to meet the rising number of youths entering the labour force each year. Poverty rates would remain relatively constant but population growth would increase the number of people living below the poverty line.

3. Implement the ERGP-The Federal Government implements macroeconomic and structural reforms and the bold initiatives contained in this Plan. ${ }^{27}$ This would involve substantially increasing public and private investment, prioritizing support for sectors with comparative and competitive advantages, tackling obstacles to doing business, providing high-quality infrastructure and promoting social inclusion. The economy would recover strongly and GDP growth would reach 7 per cent, driven by strong non-oil sector growth (7.28 per cent in 2020) and steady expansion of the agriculture, manufacturing and services sectors. Approximately 15 million net jobs would be created and poverty would decline from 61 per cent to 50-55 per cent by 2020 (Appendix 5).

\section{Nigeria Competiveness Determinants for economic powerhouse}

The Nigeria Industrial Revolution Plan (NIRP) ${ }^{27}$ was designed to accelerate the build-up of industrial capacity within Nigeria. It aims to achieve this objective by developing four industry groups where Nigeria already possesses a clear comparative advantage:

1.Agri-business and agro-allied - Maximize the benefits from the country's agricultural resources by building an end-to-end integrated agriculture value chain, boosting local production to meet local demand, and reducing the country's reliance on imports of processed food products. 2. Solid minerals and metals - Create an enabling environment targeting large-scale investors to institutionalize world-class production standards in the country's solid minerals sector.

3. Oil and gas related industries - Provide the foundation for Nigeria to build competitive oil- and gas-driven industries, encourage high value-adding downstream investments, and build institutional industrial strength within the country.

4. Construction, Light manufacturing and Services - Leverage the significant opportunities in local markets for construction (i.e., housing), light manufacturing and services offered by Nigeria's large consumer population, business demands, and infrastructure needs.

5. Develop Nigeria Knowledgepreur Ecosystem for emergence of the knowledge economy.

Knowledgepreur ecosystem framework - concept of biological ecosystem is a system that includes all living organisms (biotic factors) in an area as well as its physical environments (abiotic factors) functioning together as a unit. In contrast, an innovation ecosystem enabling the capacity for communities to innovate and improve the knowledge frontiers dynamics to create sustainable development. With the development of crowdsourcing techniques globally, the possibilities of the 
innovation ecosystem is viable. In this context, the actors/participants would include the material resources (funds, equipment, facilities, etc.) and the human capital (students, faculty, staff, industry researchers, industry representatives, etc.) that make up the institutional entities participating in the ecosystem (e.g. the universities, colleges of engineering, business schools, business firms, venture capitalists (VC), industry-university research institutes, federal or industrial supported centres of excellence, and state and/or local economic development and business assistance organizations, funding agencies, policy makers, etc.), where each component works interdependently for adaptive solution based on scenarios and value creation of promoters of projects .A simplified representation of the adaptive cycle shows these two phases in a more recognizable form The rapid growth and conservation phases are referred to as the fore-loop with relatively predictable dynamics, and in which there is a slow accumulation of capital and potential through stability and conservation. development process to ensure proper downstream execution. Commercialization is executed primarily through two organizational forms - corporations and start-ups focus encapsulate by the following:

i. Research | a studious inquiry or examination. Discovery and interpretation of facts, the revision of accepted theories or laws in light of these new facts, or practical application of such new or revised theories or laws.

ii. Development | the act of creating that which is unknown; a gradual and focused process by which anything is developed in a series of progressive steps.

iii. Commercialize | to make something available to be exploited for profit.

iv. Knowledgeprenuer is the possession of knowledge and applied experience of foresight for the creation of value and sustainable profits.

$\mathrm{v}$. Innovation value praxis is informed decision (collective intelligence) to the wellbeing and happiness of consumers.

vi. Innovation value praxis domain experts are called knowledgeprenuer ecosystem.

\section{CONCLUSIONS}

New technology drives productivity and policies that improve infrastructure and the business environment are effective in giving incentives to companies to take up the new technology and raise their productivity. But alongside these enabling policies both governments and companies need to ensure that technology is used for the common good, the quality of jobs is good, workers are proud to hold them and policies by corporates like using robots to replace workers in the pursuit of shortterm profit do not pay in the longer term. Policies relating to innovation and technology have the strongest correlation with labour market resilience for high income country like Singapore relative to Nigeria. The economic impact of violence improved by 0.2 per cent from 2018 to 2019. The biggest improvement was in armed conflict, which decreased by 29 per cent to $\$ 521$ billion, owing to a fall in the intensity of conflict in the Middle East and North Africa. ${ }^{28}$ There is a need to research the impacts of armed conflict to Nigerian economy. Knowledge-based entrepreneurial activity was affirmed to be the driving force behind economic growth, job creation and enhancing competitiveness today. The impacts, results as the multiplier driver for sustaining prosperity and raising the welfare of citizens and position the countries case studies as competitive economy.

\footnotetext{
${ }^{28}$ https://www.visionofhumanity.org/wp-content/uploads/2020/10/GPI_2020_web.pdf
} 


\section{REFERENCES}

Abramo, G., D’Angelo, C. A., Di Costa, F., and Solazzi, M. (2009). University-industry collaboration in Italy: A bibliometric examination. Technovation, 29 (6-7), 498-507.

Acs, Z. J., \& Amorós, J. E. (2008). Entrepreneurship and competitiveness dynamics in Latin America. Small Business Economics, 31 (3), 305-322.

Acs, Z. J., Desai, S., and Hessels, J. (2008). Entrepreneurship, economic development and institutions. Small Business Economics, 31 (3), 219-234.

Adamkiewicz-Drwiłło H.G., (2002). Uwarunkowania konkurencyjności przedsiębiorstw. PWN, Warszawa.

Ajitabh A., Momaya K., (2004). Competitiveness of Firms: Review of Theory, Frameworks and Models. Singapore Management Review 26 (1), 45-61

Altomonte C., Aquilante T., Ottaviano G.I.P., (2012). The Triggers of Competitiveness. The EFIGE Cross-Country Report. The Bruegel Blueprint Series, Bruegel, Brussels.

Amorós, J. E., and Bosma, N. (2014). Global Entrepreneurship Monitor: 2013 Global Report (pp. 1-104). Retrieved from http://www.gemconsortium.org.

Anholt, S. (2005). Brand new justice: How branding places and products can help the developing world. Boston: Butterworth-Heinemann.

Antonjuk, L. (2004), Mizhnarodna konkurentospromozhnist' krain: teorija ta mehanizm realizacii. Kiev: KNEU.

APSC (Australian Public Service Commission) (2007). Tackling wicked problems: A public policy perspective, Canberra Australian Public Service Commission. www.apsc.gov.au/ publications-and-media/archive/publications-archive/tackling-wicked-problems.

Audretsch, D.B., and Belitski, M. (2013). The missing pillar: the creativity theory of knowledge spill over entrepreneurship. Small Business Economics, 41: 819-836.

Awazu, Y. (2006). Managing technology alliances: The case for knowledge management. International Journal of Information Management, 26 (6), 484-493.

Ayers, J., and Dodman, D. (2010). Climate change adaptation and development. I: The state of the debate. Progress in Development Studies, 10, 161-168.

Azuma, Eiichiro. (2005). Between Two Empires: Race, History, and Transnationalism in Japanese America. New York: Oxford University Press.

Baaij, M., Greeven M., Dalen J. V. (2004). Persistent Superior Economic Performance, Sustainable Competitive Advantage, and Schumpeterian Innovation: Leading Established Computer Firms, 1954-2000. European Management Journal Vol. 22, No.5: 517-531.

Barker, T., Köhler J., (1998). Environmental Policy and Competitiveness. Environmental Policy Research Briefs 6, 1-12.

Bartelmus, P., (2003). Dematerialization and capital maintenance: two sides of the sustainability coin. Ecological Economics 46: 61-81.

Batie, Sandra S. (2008). Wicked Problems and Applied Economics. American Journal of Agricultural Economics, Volume 90, Issue 5, December 2008, Pages 1176-1191.

Baxter, J., \& Chua, W. F. (2003). Alternative management accounting research-whence and whither. Accounting Organizations and Society, 28, 97-126.

Bergsteiner, H., \& Avery, G. C. (2011). When Ethics are Compromised by Ideology: The Global Competitiveness Report. Journal of Business Ethics, 109 (4), 391- 410.

Berkes, F. (2009). Evolution of co-management: Role of knowledge generation, bridging organizations and social learning. Journal of Environmental Management, 90, 1692-1702.

Bigliardi, B., \& Galati, F. (2012). Models of adoption of open innovation within the food industry. Trends in Food Science \& Technology.

Bjerregaard, T. (2010). Industry and academia in convergence: Micro-institutional dimensions of R\&D collaboration. Technovation, 30 (2), 100-108. 
Bobba, F., Langer W., Pous J.W., (1971). Bericht über die Wettbewerbsfähigkeit der Europäischen Gemeinschaft, Brussels.

Boschma, R. (2004). Competitiveness of Regions from an Evolutionary Perspective. Regional Studies, 38 (9), 1001-1014.

Bosma, N., and Schutjens, V. (2011). Understanding regional variation in entrepreneurial activity and entrepreneurial attitude in Europe. Ann R.Eg Sci, 47, 711-742.

Bronisz, U., Heijman, W., and Miszczuk, A. (2008). Regional competitiveness in Poland: Creating an index. Jahrbuch Für Regionalwissenschaft, 28 (2).

Buckley, P.J., Pass C.L., Prescott K., (1988). Measures of International Competitiveness: A Critical Survey. Journal of Marketing Management 4 (2), 175 -200.

Burchill, Scott, (2005). The National Interest in International Relations Theory. New York: Pal-grave Macmillan.

Carney, M. (1998). The competitiveness of networked production: the role of trust and asset specificity. Journal of Management Studies, 35 (4), 457 - 479.

Chao-Hung W., Li-Chang H., (2010). The Influence of Dynamic Capability on Performance in the High Technology Industry: The Moderating Roles of Governance and Competitive Posture. African Journal of Business Management 4 (5), 562-577.

Chesbrough, H. (2007). Business model innovation: it's not just about technology anymore. Strategy \& Leadership, 35 (6), 12-17.

Clark, W. (2007). "Sustainability Science: An Emerging Interdisciplinary Frontier.” The Rachel Carson Distinguished Lecture Series. East Lansing: Michigan State University.

Comacchio, A., Bonesso, S., \& Pizzi, C. (2011). Boundary spanning between industry and university: the role of Technology Transfer Centres. The Journal of Technology Transfer.

Conklin, J.E. (2006). Dialog Mapping: Building Shared Understanding of Wicked Problems. Napa, CA: Cog Nexus Institute.

Corcoran, P. B., Walker, K. E., \& Wals, A. E. J. (2004). Case studies, make your case studies, and case stories: a critique of case study methodology in sustainability in higher education. Environmental Education Research, 10 (1), 7-21.

Collier, P. (2008). Oil, Growth and Governance in Nigeria. In: P. Collier, C. C. Soludo, \&

C. Pattillo (Eds.), Economic Policy Options for a Prosperous Nigeria (pp. 45-59).

BasingstokeHampshire: Palgrave Macmillan. Retrieved

fromhttp://www.palgrave.com/page/detail/economic-policy-options-for-a-prosperousnigeria-paulcollier/?K=9780230542730

Cuckovic, N., \& Bartlett, W. (2007). Entrepreneurship and Competitiveness: The Europeanisation of Small and Medium-sized Enterprise Policy in Croatia. Southeast European and Black Sea Studies, 7 (1), 37-56.

Cunska, Zane, Christian Ketels, Anders Paalzow, Alf Vanags (2013), Latvia Competitiveness Report 2013, Stockholm School of Economics in Riga/ Baltic International Centre for Economic Policy Studies: Riga.

D'Este, P., and Patel, P. (2007). University-industry linkages in the UK: What are the factors underlying the variety of interactions with industry? Research Policy, 36 (9), 1295-1313. Davis, Stan and Christopher Meyer (1998), Blur: The Speed of Change in a Connected Economy, Ernst and Young Centre for Business Innovation.

Deimel, M., Theuvsen, L., and Ebbeskotte, C. (2010). Regional networking as a competitive advantage? Empirical results from German pig production. Food Economics - Acta Agriculturae Scandinavica, Section C, 7 (2-4), 163-179.

Dentoni, D., Hospes, O., and Ross, R. B. (2012). "Managing Wicked Problems in Agribusiness: The Role of Multi-Stakeholder Engagements in Value Creation." International Food and Agribusiness Management Review 15: 1-12. 
Duckett, D, Feliciano, D, Martin-Ortega, J et al. (1 more author) (2016).Tackling wicked environmental problems: The discourse and its influence on praxis in Scotland. Landscape and Urban Planning, 154. pp. 44-56. ISSN 0169-2046.

Dunne, Tim and Brian C. Schmidt, (2005). Realisme, In: John Baylis and Steve Smith (eds.), The Globalization of World Politics: An Introduction to International Relations. Third Edition. Oxford: Oxford University Press.

Durant, R.F. and Legge, J.S. (2006). 'Wicked problems', public policy, and administrative theory: Lesson from the GM Food Regulatory. Arena, Administration \& Society, Vol 38, No 3, pp 309-34.

Etzkowitz, H. (2008). The Triple Helix: University-Industry-Government Innovation in Action. Engineering (1st ed., p. 164). Oxon: Routledge.

Etzkowitz, H., \& Klofsten, M. (2005). The innovating region: toward a theory of knowledge-based regional development. $R$ and D Management, 35 (3), 243-255.

European Commission, (2001). European Competitiveness Report 2001. DG for Enterprise and Industry, Brussels.

Fendel, R., \& Frenkel, M. (2005). The International Competitiveness of Germany and other European Economies : The Assessment of the Global Competitiveness report. Intereconomics, 1, 29-35.

Ferlie, E., Fitzgerald, L., McGivern, G., Dopson, S., and Bennett, C. (2011). Public policy networks and 'wicked problems': A nascent solution? Public Administration, 89 (2), 307 324.

Fischer, A. R. H., P. J. Beers, H. van Latesteijn, K. Andeweg, E . Jacobsen, H. Mommaas, and A. Veldkamp (2012). Transform system innovation towards sustainable food. A review. Agronomy for Sustainable Development 1-14.

Flejterski, S., (1984). Istotaimierzenie konkurencyjności międzynarodowej. Gospodarka Planowa 9, 390-394.

Funtowicz, S.O., and J.R. Ravetz. (1993). "Science for the Post-normal Age.” Futures 25 (7) $739-55$.

Garnsey, E., Smith, H. L. (1998). Proximity and Complexity in the Emergence of High Technology Industry: The Oxbridge Comparison. Geoforum, 29 (4), 433-450.

Gillingham, P. and Humphreys, C. (2010) .Child protection practitioners and decision- making tools: Observations and reflections from the front line, British Journal of Social Work, Vol. 40, no 8, pp 2598-616.

Glebocka, K. (1997). Evolucja integracja gospodarczaj w Unit europejskiej. Gdansk, Universytet Gdanski.

Goel, V., Dolan, R. J. (2004). Differential involvement of left prefrontal cortex in inductive and deductive reasoning. Cognition, 93 (3), B109-21.

Greyling, S., Patel, Z. and Davison, A. (2016). Urban sustainability disjunctures in Cape Town: Learning the city from the inside and out, Local Environment, 1-14.

Guerrero, M., \& Urbano, D. (2010). The development of an entrepreneurial university. The Journal of Technology Transfer, 37 (1), 43-74.

Guerrero, M., Rialp, J., \& Urbano, D. (2006). The impact of desirability and feasibility on entrepreneurial intentions: A structural equation model. International Entrepreneurship and Management Journal, 4(1), 35-50.

Guo, B., \& Guo, J.-J. (2011). Patterns of technological learning within the knowledge systems of industrial clusters in emerging economies: Evidence from China. Technovation, 31 (2-3), 87-104.

Guston, D.H. (2001). "Boundary Organizations in Environmental Policy and Science." Science, Technology and Human Values 26 (4):399 - 408. 
Hausmann, R., Rodrik D. and Velasco A. (2005), Growth Diagnostics, John F. Kennedy School of Government, Harvard University, Boston.

Hausmann, Ricardo, César A. Hidalgo, Sebastián Bustos, Michele Coscia, Sarah Chung, Juan Jimenez, Alexander Simoes, and Muhammed A. Y1ldirım (2012), The Atlas of Economic Complexity, Centre for International Development/MIT Media Lab: Cambridge, MA.

Head, B.W. (2008). Wicked problems in public policy, Public Policy Vol 3, no 2, pp 101-18.

Head, B.W. (2010). How can the public sector resolve complex issues: Strategies for steering, administering and coping, Asia-Pacific Journal of Business Administration Vol 2, no 1, $8-16 \mathrm{pp}$.

Head, B.W. (2014). Evidence, uncertainty, and wicked problems in climate change decision making in Australia, Environment and Planning C: Government and Policy, Vol 32, no 4, pp 663-79.

Head, B.W. and Alford, J. (2015) .Wicked problems: Implications for public policy and management, Administration \& Society Vol 47, no 6, pp 711-39.

Heifetz, R.A. (1994). Leadership without easy answers, Cambridge, M.A: Harvard University Press.

Hollensen, S., (2010). Global Marketing: A Decision-Oriented Approach. Financial Times/Prentice Hall.

Hoppe, R. (2011). The Governance of Problems: Puzzling, Powering and Participation. Policy Press.

Hoskisson, R. E., Covin, J., Volberda, H. W., \& Johnson, R. (2011).Revitalizing Entrepreneurship: The Search for New Research Opportunities. Journal of Management Studies, 48 (6), 1141-1168.

Huggins, R., \& Williams, N. (2011). Entrepreneurship and regional competitiveness: The role and progression of policy. Entrepreneurship \& Regional Development, 23 (9-10), 907-932.

IMD (2008). World Competitiveness Yearbook 2008. Institute for Management Development. Lausanne, Switzerland.

International Monetary Fund (2015). Article IV consultation with Ireland, International Monetary Fund, Washington, D.C.,

Isaksen, A. (1997). Regional clusters and competitiveness. The Norwegian case. European Planning Studies, 5 (1), 65-76.

Johnson, C. F. (1996). Deductive Versus Inductive Reasoning: A Closer Look at Economics. The Social Science Journal, 33 (3), 287-299.

Ketels, C. H. M. (2006). Michael Porter's Competitiveness Framework- Recent Learnings and New Research Priorities. Journal of Industry, Competition and Trade, 6 (2), 115-136.

Klodawsky, F. (2009). Home spaces and rights to the city: Thinking social justice for chronically homeless women, Urban Geography Vol. 30, No 6, pp 591-610.

Koppenjan, J., and E. H. Klijn. (2004). Managing Uncertainties in Networks: A Network Approach to Problem Solving and Decision Making. London: Routledge.

Kravchenko, N. A., Bobylev, G. V., Valieva, O. V., \& Fedorov, A.A. (2013). Competitiveness on the basis of innovation: The international position of Russia. Studies on Russian Economic Development, 24 (5), 461- 469.

Krugman P., (1990). The Age of Diminished Expectations. The MIT Press, Cambridge.

Krugman P., (1994). Competitiveness: A Dangerous Obsession. Foreign Affairs 73 (2), 28-44.

Lall, S. (2001). Competitiveness, Technology and Skills. Cheltenham: Edgar Elgar.

Lall, Sanjaya (2001), Comparing National Competitive Performance: An Economic Analysis of World Economic Forum's Competitiveness Index, QEH Working Paper No. 61, Oxford University: Oxford. 
Lang, T., and Barling, D. (2012). "Food Security and Food Sustainability: Reformulating the Debate." Geographical Journal 178 (4): 313-26.

Lawton. Smith, H., and Bagchi-Sen, S. (2012). The Research University, entrepreneurship and regional development: Research propositions and current evidence. Entrepreneurship \& Regional Development, 24 (5-6), 383- 404.

Lawton, Smith, H., Glasson, J., Romeo, S., Waters, R., \& Chadwick, a. (2013). Entrepreneurial regions: Evidence from Oxfordshire and Cambridgeshire. Social Science Information, 52 (4), 653-673.

Lazarus, R.J. (2009). Super wicked problems and climate change, restraining the present to liberate the future, Cornell Law Review 94, 5.

Lech, A., (2001). Definicjeimiary międzynarodowej konkurencyjności gospodarki. Gospodarkaw teorii ipraktyce 2 (9), 77-86.

Levin, K., Cashore, B., Steven Bernstein, S., and Auld, G. (2009). Playing it forward: Path dependency, progressive incrementalism, and the "Super Wicked" problem of global climate change. IOP Conference Series: Earth and Environmental Science 50 (6).

Leydesdorff, L. (2011). The Triple Helix, Quadruple Helix, and an N-Tuple of Helices: Explanatory Models for Analyzing the Knowledge-Based Economy? Journal of the Knowledge Economy.

Leydesdorff, L., and Sun, Y. (2009). National and International Dimensions of the Triple Helix in Japan: University-Industry - Government versus International Co-authorship Relations.

Journal of the American Society for Information Science and Technology, $60 \quad$ (4), 778788.

Lichtenthaler, U. (2010). Technology exploitation in the context of open innovation: Finding the right "job" for your technology. Technovation, 30 (7-8), 429-435.

Lin, H.-M., Huang, H.-C., Lin, C.-P., \& Hsu, W.-C. (2012). How to manage strategic alliances in OEM-based industrial clusters: Network embeddedness and formal governance mechanisms. Industrial Marketing Management, 41 (3), 449-459.

Luo, J., Olechowski A. L., Magee C. L. 2012. Technology-based design and sustainable economic growth. Technovation 1-15.

Marques, C. S., Ferreira, J., Rodrigues, R. G., \& Ferreira, M. (2010). The contribution of yoga to the entrepreneurial potential of university students: a SEM approach. International Entrepreneurship and Management Journal, 7 (2), 255-278.

Marques, J. P. C., Caraça, J. M. G., Diz, H. (2006). How can university-industry-government interactions change the innovation scenario in Portugal? - The case of the University of Coimbra. Technovation, 26 (4), 534-542.

McGahan A.M., (1999). Competition, Strategy and Business Performance. California Management Review 41 (3), 74-101.

Melnikas, B. (2004). Regional Economic Development in the System of EU Economy: Efficiency, Competitiveness, the Idea of "Oases" // Inžinerine ekonomika. 3 (38): 39-48.

Meriküll, J., Strikholm B. and Viilmann N. (2015), Estonian Competitiveness Report 2015, Eesti Pank, Tallinn.

Miller, C.A. (1999). "Report of the Workshop on Boundary Organizations in Environmental Policy and Science.” Bloustein School of Planning and Public Policy, Rutgers University, New Brunswick, N.J, December 9-10.

Norton, B.G. (2005). Sustainability: A Philosophy of Adaptive Ecosystem Management. Chicago, IL: University of Chicago Press.

Novais A. L. M., João B. N., Serralvo F. A. (2012). Sustainability as a topic in business and management research: A bibliometric analysis. African Journal of Business Management 6 (22): 6587- 6596. 
Nowotny, H., P. Scott, and M. Gibbons. (2001). Re-thinking Science: Knowledge and the Public in an Age of Uncertainty. Cambridge, UK: Polity Press.

Obajilu, S. and Obi, E. (2003). Government and Politics of Nigeria: The Struggle for Power in African States. Onitsha: Book Point Limited.

OECD (2008), Handbook on Constructing Composite Indicators: Methodology and User Guide, OECD/ JRC European Commission: Paris/Seville.

Ojewale, B. A., Ilori, M. O., Oyebisi, T. O., Akinwumi, I. O. (2001). Industry-academic - relation: utilization of idle capacities in polytechnics, universities and research organizations by entrepreneurs in Nigeria. Technovation, 21, 695-704.

Okonjo-Iweala, N., \& Osafo-Kwaako, P. (2007). Nigeria's Economic Reforms: Progress and Challenges. Washington.

Otaiku, A.A. (2020). Trickling Wicked Problems in Agriculture Farm In-puts for Sustainable Crop Production: Products development and Meta-Data Analyses. The Nigerian Society for Plant Protection, $45^{\text {th }}$ Annual Conference, University of Uyo, Nigeria, Keynote Address.

Otaiku, A.A, (2018). A Framework for Hybrid Warfare: Threats, Challenges and Solutions J. Def. Management, 8: 3 DOI: 10.4178/2167-0374.1000178.

Otaiku, A. A (2020a). National Interest and Warfare Ecosystem 1: Global Balance-of-Power Strategies International Journal of International Relations, Media and Mass Communication Studies Vol.6, No.3, pp.72-108, December 2020 Published by ECRTDUK Print ISSN: 2059-1845, Online ISSN: 2059-1853.

Otaiku, A.A (2020b). National Interest and Warfare Ecosystem 2: Wicked Problems Framework and Policy Development. International Journal of International Relations, Media andMass Communication Studies Vol.6, No.3, pp.14-67, December 2020 Published by ECRTD- UK Print ISSN: 2059-1845, Online ISSN: 2059-1853.

Overmars, K. P., Verburg, P. H., \& Veldkamp, T. A. (2007). Comparison of a deductive and an inductive approach to specify land suitability in a spatially explicit land use model. Land Use Policy, 24 (3), 584-599.

Perkmann, M., Neely, A., and Walsh, K. (2011). How should firms evaluate success in universityindustry alliances? A performance measurement system. $R \& D$ Management, 41(2), 202-216.

Perkmann, M., Tartari, V., McKelvey, M., Autio, E., Broström, A., D’Este, P. Sobrero, M. (2013). Academic engagement and commercialisation: A review of the literature on universityindustry relations. Research Policy, 42 (2), 423-442.

Peterson, C. (2008). "Transformational Supply Chains and the 'Wicked Problem' of Sustainability: Aligning Knowledge, Innovating, Entrepreneurship, and Leadership.” Keynote address presented at the International Chain Conference, Wageningen, The Netherlands, 29 May.

Peterson, H. C. (2009). Transformational supply chains and the 'wicked problem' of sustainability: Aligning knowledge, innovation, entrepreneurship, and leadership. Journal on Chain and Network Science 9 (2): 71-82.

Philbin, S. (2008). Process model for university-industry research collaboration. European Journal of Innovation Management, 11 (4), 488-521.

Pichler, F. (2012), Cosmopolitanism in a global perspective: An international comparison of open-minded orientations and identity in relation to globalization, International Sociology, Vol. 27.

Porter, M., Ketels C., Delgado M., (2008). The Microeconomic Foundations of Prosperity: Findings from the Business Competitiveness Index. In: WEF, The Global Competitiveness Report 2007-2008 WEF, Geneva. 
Porter, M. E. (1990).The Competitive Advantage of Nations ( $1^{\text {st }}$ ed.). New York, NY: Free.

Porter, M. E. (1998). Clusters and the New Economics of Competition. Harvard Business Review, 11-12, 75-90.

Prainsack, B. (2012). Elias G. Carayannis and David F. J. Campbell, Mode 3 Knowledge Production in Quadruple Helix Innovation Systems: 21st-Century Democracy, Innovation, and Entrepreneurship for Development. Minerva, 50 (1), 139 - 142.

Ranga, L. M., Debackere, K., \& Tunzelmann, N. Von. (2003). Entrepreneurial universities and the dynamics of academic knowledge production: A case study of basic vs . applied research in Belgium. Scientometrics, 58 (2), 301-320.

Regeringskansliet (Swedish Government Office) (2015), Sveriges företagande och konkurrenskraft - internationell jämförelse (Swedish entrepreneurship and competitiveness - international comparison), Ds 2015:43, Swedish Government Office: Stockholm.

Reynolds, P., Bosma, N., Autio, E., Hunt, S., De Bono, N., Servais, I.,Chin, N. (2005). Global Entrepreneurship Monitor: Data Collection Design and Implementation 1998-2003. Small Business Economics, 24 (3), 205-231.

Rittel, H.W.J. and Webber, M.M. (1973). Dilemmas in a general theory of planning, Policy Sciences Vol 4, No 2, pp 155-69.

Roberts, N. (2000). Wicked problems and network approaches to resolution, International Public Management Review Vol 1, no 1, pp 1-19.

Rodrik, D. (2007). How to Save Globalization from its Cheerleaders, Journal of International Trade and Diplomacy, Vol 1, No 2.

Rossi, F. (2013). Indicators of university-industry knowledge transfer performance and their implications for universities: Evidence from the U.K' s HE-BCI survey (WP13) (pp. 1-24). London.

Ruttan, V.W., D.E. Bell, and W.C. Clark. (1994). "Climate-Change and Food Security Agriculture, Health and Environmental Research." Global Environmental Change- Human and Policy Dimensions 4 (1) : $63-77$.

Schwab, K., Sala-i-Martin X., (2013). The Global Competitiveness Report 2013-2014. World Economic Forum, Geneva.

Schwab, K. (2009). The Global Competitiveness Report 2009-2010. World Economic Forum. Geneva, Switzerland.

Schwab, K. (2013). The global competitiveness report 2013-2014 (p. 569). Geneva. Retrieved fromhttp://www.weforum.org/pdf/Global_Competitiveness_ Reports/Reports/factsheet_gcr03.pdf.

Schwab, K. (2014). The Global Competitiveness Report 2014-2015. (World Economic Forum, Ed.) (pp. 1-549). Geneva: World Economic Forum.

Schwab, K. and Porter, M. E. (2007). The Global Competitiveness Report 2007-2008. World Economic Forum. Geneva, Switzerland.

Scott, B.R., Lodge G.C., (1985). US Competitiveness in the World Economy. Harvard Business School Press, Boston.

Seddon, T. (2016). Inventing drugs: Genealogy of a regulatory concept, Journal of Law and Society Vol 43, no 3, pp 393 - 415.

Semlinger, K. (2008). Cooperation and competition in network governance: regional networks in a globalised economy. Entrepreneurship \& Regional Development, 20 (6), 547-560.

Singh, S., Corner, P. D., \& Pavlovich, K. (2014). Failed, not finished: A narrative approach to understanding venture failure stigmatization. Journal of Business Venturing.

Sivertsen, T. H. (2005). Discussing the scientific method and a documentation system of meteorological and biological parameters. Physics and Chemistry of the Earth, Parts $\mathrm{A} / \mathrm{B} / \mathrm{C}, 30$ (1-3), 35-43. 
Stajano, A. (2006). Research, Quality, Competitiveness: European Union Technology Policy for the Information Society (pp. 1 - 462). New York, NY: Springer USA.

Stephenson, K., and L. Shabman. (2007). "Overview of Computer-Aided Dispute Resolution: Approach and Evaluation.” In: K. Stephenson, L. Shabman, S. Langsdale, and H. Cardwell, eds. Computer Aided Dispute Resolution: Proceedings from the CADRe Workshop. Albuquerque, New Mexico.

Termeer, C.J.A.M., Dewulf, A., Breeman, G. and Stiller, S.J. (2015). Governance capabilities for dealing with wicked problems, Administration \& Society Vol 47, no 6, pp $680-710$.

Tee, N. P. (2005). Innovation and Enterprise in Singapore Schools. Educational Research for Policy and Practice, 3 (3), 183-198.

Tranfield, D., Denyer, D., \& Smart, P. (2003). Towards a Methodology for Developing EvidenceInformed Management Knowledge by Means of Systematic Review. British Journal of Management, 14 (3), 207-222.

Turnbull, L. (2010). The 'wicked problem' of fiscal equality for women, Canadian Journal of Women and the Law Vol. 22, no 1, pp 213 -39.

Tyson, D'Andrea L., (1992). Who's Bashing Whom: Trade Conflict in High Technology Industries? Institute for International Economics, Washington, D.C.

Van Latesteijn, and Rabbingeb (2012). Wicked Problems in Sustainable Agriculture and Food Security, the Trans Forum Experience. International Food and AgribusinessManagement Review Volume 15, Special Issue B.

Van Looy, B., Ranga, M., Callaert, J., Debackere, K., \& Zimmermann, E. (2004). Combining entrepreneurial and scientific performance in academia: towards a compounded and reciprocal Matthew-effect? Research Policy, 33 (3), 425-441.

Vaz, E., de Noronha Vaz, T., Galindo, P. V., \& Nijkamp, P. (2014). Modelling innovation support systems for regional development - analysis of cluster structures in innovation in Portugal. Entrepreneurship \& Regional Development, 26 (1-2), 23-46.

Webber, E.P. and Khademian, A.M. (2008). Wicked problems, knowledge challenges, and collaborative capacity builders in network settings, Public Administration Review, Vol 68, No 2, pp 334-49.

White, L.G. (1994). "Policy Analysis as Discourse." Journal of Policy Analysis and Management 13 (3):506-25.

World Economic Forum, (2011), “Global Competitiveness Report 2011-2012”, Geneva.

Wziątek-Kubiak , A. (2003). Konkurencyjność polskiego przemysłu. Wyd. Bellona, Warszawa. Yasuda, H., and Iijima, J. (2005). Linkage between strategic alliances and firm's business strategy: the case of semiconductor industry. Technovation, 25 (5), 513-521.

Yew, L.K. (2000). From Third World to First, Harper Collins, New York.

Yin, R. K. (2014). Case study research: design and method (Fifth edit., pp. 1-265). California: Sage publications, Inc.

ZEW Economic Studies. (2004). Europe's Automotive Industry on the Move: Competitiveness in a Changing World. (O. Heneric, G. Licht, \& W. Sofka, Eds.) (pp. 1-280). New York: Physica-Verlag (Springer). 


\section{APPENDICES}

\section{Appendix 1. Global Manufacturing Competitiveness Index: Country rankings | 2020}

Table 2 | Global CEO survey: 2016 Global Manufacturing Competitiveness Index rankings by country.

\begin{tabular}{|c|c|c|c|c|c|c|}
\hline \multicolumn{3}{|c|}{2016 (Curent) } & \multicolumn{4}{|c|}{2020 (Projected) } \\
\hline Rank & County & $\begin{array}{l}\text { Index scope } \\
(100=H i g h) \\
(10=\text { Low })\end{array}$ & Rank & $\begin{array}{l}2016 \mathrm{vs} \\
2020\end{array}$ & County & $\begin{array}{c}\text { Index scope } \\
(100=H i g h) \\
(10=L \mathrm{LW})\end{array}$ \\
\hline 1 & China & 1000 & 1 & $(\Lambda+1)$ & United States & 1000 \\
\hline 2 & United States & 99.5 & 2 & $(\nabla \cdot 1)$ & China & 93.5 \\
\hline 3 & Germany & 93.9 & 3 & $\Leftrightarrow$ & Germany & 90.8 \\
\hline 4 & Japan & 80.4 & 4 & $\Leftrightarrow$ & Japan & 78.0 \\
\hline 5 & South Korea & 76.7 & 5 & $(1+6)$ & India & 77.5 \\
\hline 6 & United Kingdom & 75.8 & 6 & $(7 \cdot-1)$ & South Kored & 77.0 \\
\hline 7 & Taiwan & 72.9 & 7 & $(\Delta+1)$ & Mexico & 75.9 \\
\hline 8 & Mexico & 69.5 & 8 & $(7 \cdot 2)$ & United Kingdom & 73.8 \\
\hline 9 & Canada & 68.7 & 9 & $(7 \cdot 2)$ & Taiman & 72.1 \\
\hline 10 & Singapore & 68.4 & 10 & $(7 \cdot 1)$ & Canada & 68.1 \\
\hline 11 & India & 67.2 & 11 & $(7 \cdot 1)$ & Singapore & 67.6 \\
\hline 12 & Switzelland & 63.6 & 12 & $(\Delta+6)$ & Vietnam & 65.5 \\
\hline
\end{tabular}


Appendix 2. Competitive Industrial Performance Report 2020

\section{Competitive Industrial Performance index 2020}

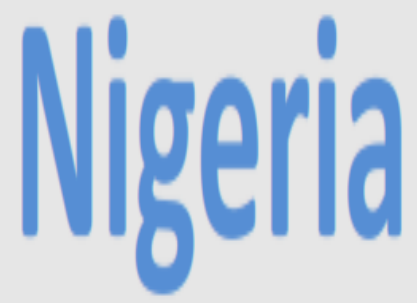

Africa

Other Developing Economies

Lower Middle Income

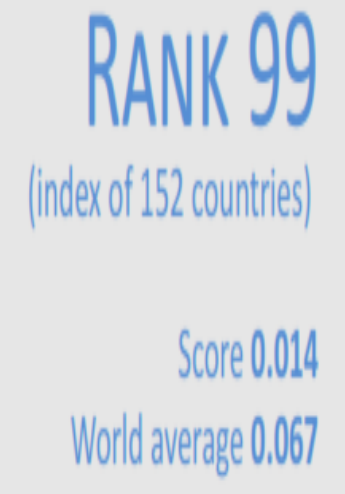

\section{Manufacturing sector summary (2018)}

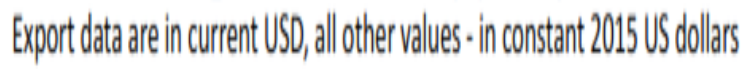
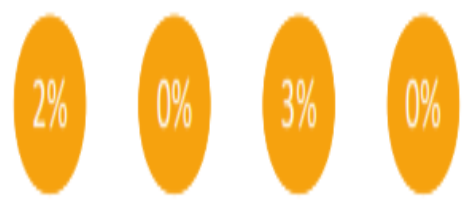

GPP:500.billion |2.55 per capita

Manufatcuring value a ddeded: 45.66 billion $\mid 233$ per capita

Manufaturinge exports: 3,505million | 18.0per capita

Seeful manufacturing profle at st tat, unido, orge/country-profilie

Readers Guide: stat, unido, org/content/learning-center/cip-readers-guide
$52.8 \%$

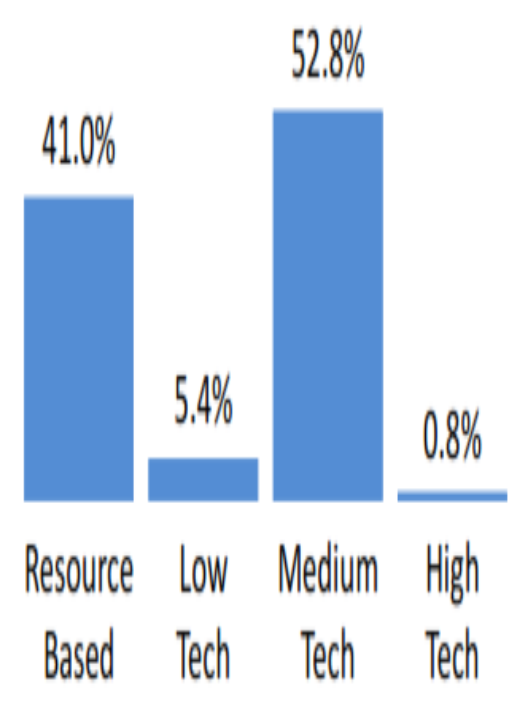


Competitive Industrial Performance Index 2020

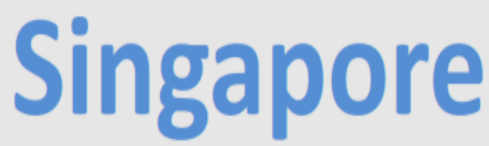

Asia and Pacific

Industrialized Economies

High Income
RANK 9

(index of 152 countries)

Score $\mathbf{0 . 2 5 9}$

World average 0.067

Manufacturing sector summary (2018)

Export data are in current USD, all other values - in constant 2015 US dollars
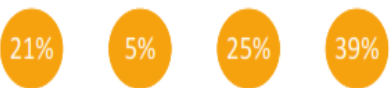

$43.1 \%$

GDP: 332.8 billion | 57,799 per capita

Manufacturing value added: 63.2 billion | 10,974 per capita

Manufacturing exports: 186.2 billion | 32,344 per capita

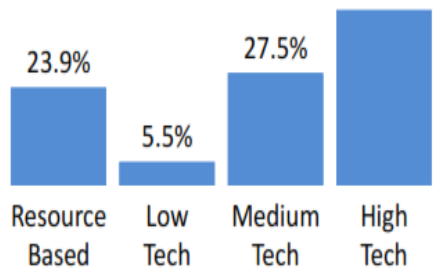

See full manufacturing profile at stat unido org/country-profile

Readers Guide: stat . unido . org/content/learning-center/cip-readers-guide

Based Tech Tech Tech 


\section{Appendix 3. Global Labour Resilience}

\section{- Nigeria}

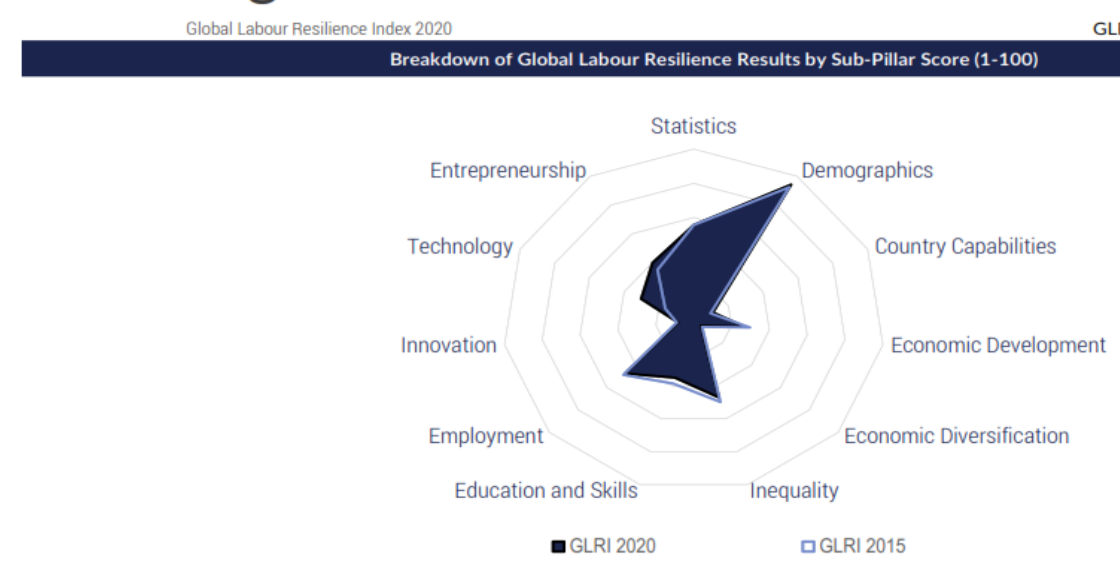

\begin{tabular}{|c|c|c|c|c|c|c|c|c|c|c|c|}
\hline \multicolumn{12}{|c|}{ Breakdown of Global Labour Resilience Results by Indicator } \\
\hline \multirow{2}{*}{$\begin{array}{l}\text { Variable } \\
\text { 1. Structural Pillar }\end{array}$} & \multirow[t]{2}{*}{ Value } & \multirow{2}{*}{$\begin{array}{c}\text { Score } \\
21\end{array}$} & \multirow{2}{*}{$\begin{array}{c}\begin{array}{c}\text { GLRI } \\
2020 \text { rank }\end{array} \\
139\end{array}$} & \multicolumn{2}{|c|}{$\begin{array}{l}\text { Rank change } \\
\text { GLRI 2015-2020 }\end{array}$} & \multirow{2}{*}{ Variable } & \multirow{2}{*}{$\begin{array}{l}\text { Value } \\
377111\end{array}$} & \multirow{2}{*}{ Score } & \multirow{2}{*}{$\begin{array}{c}\begin{array}{c}\text { GLRI } \\
\text { 2020 ranl }\end{array} \\
69\end{array}$} & \multicolumn{2}{|c|}{$\begin{array}{r}\text { Rank change } \\
\text { kL GLRI 2015-202 }\end{array}$} \\
\hline & & & & $\Delta$ & 1 & & & & & $\nabla$ & -1 \\
\hline 1.1 Demographics & & 94 & 16 & $\Delta$ & $\mathrm{I}$ & 2.22.6 ALP effectiveress (1.7 survey) & 2.1 & 15 & 118 & $\Delta$ & 3 \\
\hline 1.1.1 Share of older population (s of total population) & 27 & 94 & 16 & $\Delta$ & 1 & 2.22 .7 Labour-employer cooperation (1-7 survey) & 3.9 & 23 & 116 & $\nabla$ & -17 \\
\hline 1.2 Country Capabilities & & & 122 & & & $2.22 .8 \mathrm{imp}$ act of taxes on workers (1.7 survey) & 5.1 & 74 & 7 & $\Delta$ & 29 \\
\hline 12.1 Economic Complexity index & -1.7 & 11 & 122 & $\nabla$ & -1 & 2.22 .9 Earnings quality (PPP) & $n / a$ & $\mathrm{n} / \mathrm{a}$ & n/a & & \\
\hline 1.3 Economic Development & & & & & , & 2.22 .10 quality of the working environment $(\mathrm{s})$ & $\mathrm{n} / \mathrm{a}$ & $\mathrm{n} / \mathrm{a}$ & $\mathrm{n} / \mathrm{a}$ & & \\
\hline 1.3 .1 lncome per capita (PPP) & 5316 & 8 & 109 & $\nabla$ & -5 & & & & & & \\
\hline 1.32 Dependence on natural resources ( $\%$ of GDP) & 87 & 40 & 109 & $\Delta$ & $i$ & 2.3 Innovation & & 8 & 127 & $\nabla$ & 3 \\
\hline 1.3.3 Tertiarisation of economy ( $\%$ of GDP) & 520 & 59 & 90 & $\nabla$ & 9 & 2.3.1 Innovation input & & 15 & 119 & $\bullet$ & 0 \\
\hline 1.4 Economic Diversification & & 5 & 141 & $\nabla$ & 2 & 23.1.1 R\&D spendings (\% of GDP) & 0.2 & 8 & 92 & $\nabla$ & -2 \\
\hline 1.4.1 Concentration of exports & 0.8 & 2 & 142 & $\nabla$ & -1 & 2.3.1.21PR soore & 3.9 & 21 & 117 & $\bullet$ & 0 \\
\hline 1.42 Diversity & 55 & 9 & 122 & $\nabla$ & -3 & & & & & & \\
\hline 1.5 Inequality & & 47 & 100 & $\nabla$ & 2 & 232 Innovation output & & 2 & 125 & $\nabla$ & -9 \\
\hline 1.5 .1 income inequality & 43.0 & 47 & 100 & $\nabla$ & -2 & 2.32 .1 Trademark applications per th. pop. & 0.1 & 4 & 121 & $\nabla$ & -4 \\
\hline & & & & & & 2.322 Patent applications per th. pop. & 0.00 & 3 & 105 & 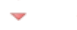 & -1 \\
\hline 2. Policy Pillar & & 31 & 111 & $\nabla$ & -6 & 2.32 .3 A\&D jourmals per th. pop. & 0.02 & 2 & 103 & $\nabla$ & -5 \\
\hline 2.1 Education and skills & & 35 & & - & .13 & 2.3.2.4 Researchers in RSD per min.pop. & 39 & 1 & 104 & $\bullet$ & 0 \\
\hline 21.1 Education and skills input & & 51 & 61 & $\nabla$ & -13 & 232.5 Technicians in ReD per min pop. & 13 & 2 & 95 & $\Delta$ & 1 \\
\hline 2.1.1. Government education spendings (" of GDP) & 3.1 & 24 & 111 & $\nabla$ & -3 & 2.32 .6 Creative goods exports (\% of goods exp.) & 0.00 & 1 & 107 & $\nabla$ & -29 \\
\hline 21.1.2 Tertiary public education spendings (\% of govexp) & 43.1 & 89 & 4 & $\nabla$ & -2 & & & & & & \\
\hline 21.1.1.3 Gov. and hh spending per tertiary student (PPPS) & $n / a$ & $\mathrm{n} / \mathrm{a}$ & $n / a$ & & & 2.4 Technology & & 30 & 124 & - & 0 \\
\hline 21.1.4 Years of schooling & 82 & 54 & 90 & $\nabla$ & -11 & 2.4 .1 Technology ingut & & 38 & 118 & $\Delta$ & 7 \\
\hline 21.1.5 Staff training (1-7 sumvey) & 3.7 & 36 & 88 & $\nabla$ & -17 & 2.4.1.1 ICT afflordability & 4.3 & 57 & 99 & $\Delta$ & 24 \\
\hline & & & & & & 2.41.21 $1 \mathrm{CT}$ rocess index & 2.6 & 18 & 119 & $\nabla$ & -5 \\
\hline 21.2 Education and skills output & & 27 & 134 & $\nabla$ & -12 & & & & & & \\
\hline 21.21 Tertiary attainment rate ( $(s$ of pop $25+)$ & 9.0 & 20 & 73 & $\nabla$ & -7 & 2.42 Technology output & & 26 & 120 & $\nabla$ & -22 \\
\hline 21.22 PISA score & $n / a$ & $\mathrm{n} / \mathrm{a}$ & n/a & & & 2.42 .1 ICT goods and services expot (\% of exp.) & 8.1 & 35 & 69 & $\Delta$ & 19 \\
\hline 21.23 Shilistet of graduates $(1-7$ survey $)$ & 29 & 20 & 134 & $\nabla$ & -1 & 24.22 Mobile broadband per 100 pop. & 21.8 & 14 & 120 & $\nabla$ & -41 \\
\hline 21.24 Shilled labour supply (1-7 survey) & 3.8 & 47 & 95 & $\nabla$ & -23 & & & & & & \\
\hline 21.25 Vocational enrolliment ( $\%$ of students) & $\mathrm{N} / \mathrm{a}$ & $\mathrm{n} / \mathrm{a}$ & n/a & & & 2.5 Entrepreneurship & & 40 & 117 & $\nabla$ & -1 \\
\hline 21.26 Vocational enrolliment of $15-24 \mathrm{dds}$ (") & $n / a$ & $n / a$ & n/a & & & 2.5. Entrepreneurship inpur & & 65 & 83 & $\Delta$ & 1 \\
\hline 21.27 Quality of vocational education (1-7 survey) & 29 & 16 & 134 & $\nabla$ & -1 & 2.5.1.1 Time dealing with gov. regulations $(\%)$ & 7.5 & 74 & 59 & $\nabla$ & -7 \\
\hline 21.28 STEM graduates (\%) & $\mathrm{n} / \mathrm{a}$ & $n / a$ & $\mathrm{n} / \mathrm{a}$ & & & 25.1 .2 Time to start a business (days) & 10.9 & 79 & 62 & A & 42 \\
\hline 21.29 Digital skills (1-7 survey) & 3.3 & 31 & 119 & $\nabla$ & -4 & 2.51.3 Procedures to register a business & 8.0 & 45 & 92 & $\vec{\nabla}$ & .17 \\
\hline 21.210 Critical thinking (1-7 suney) & 25 & 16 & 128 & $\nabla$ & -5 & $2.51 .4 \cos$ t to start a business ( $\% \mathrm{GN}$ per cap) & 28.8 & 43 & 111 & A & 2 \\
\hline 2.2 Employment & & 47 & 52 & $\Delta$ & 8 & 2.52 Entrepreneurship output & & 20 & 133 & $\nabla$ & -3 \\
\hline 221 Employment input & & 53 & 46 & $\Delta$ & 7 & 2.52 .1 Global Entrepreneurship Index & 19.7 & 15 & 93 & $\nabla$ & -13 \\
\hline 22.1.1 Hiring and fring practices (1.7 survey) & 4.6 & 69 & 16 & $\nabla$ & -7 & 2.52 .2 New cocporate registrations per th pop. & 0.4 & 6 & 79 & $\bullet$ & 0 \\
\hline 221.2 Waker's nights $(1-7$ score) & 60.8 & 16 & 99 & A & 12 & 2.52 .3 venture capial investments (\% of GDP) & $\mathrm{n} / \mathrm{a}$ & $\mathrm{n} / \mathrm{a}$ & $\mathrm{n} / \mathrm{a}$ & & \\
\hline 22.13 Hiring of foreign labour (1-7 survey) & 4.5 & 65 & 32 & $\nabla$ & -1 & 2.52 .4 SME outstanding loans (s of loans) & $n / a$ & n/a & $\mathrm{n} / \mathrm{a}$ & & \\
\hline 22.1 .4 Tax wedge (s of labour cost) & $n / a$ & $\mathrm{n} / \mathrm{a}$ & $\mathrm{n} / \mathrm{a}$ & & & 2.52 .5 Access to loans ( $(1.7$ survey) & 2.6 & 29 & 133 & $\nabla$ & $=2$ \\
\hline 221.5 ALP spendings (\% of GDP) & n/a & $n / a$ & n/a & & & & & & & & \\
\hline & & & & & & 2.6 Statistics & & 66 & 100 & $\bullet$ & \\
\hline 222 Employment output & & 44 & 54 & $\Delta$ & 6 & 2.6 .1 Statistical fullness $(\%)$ & 0.78 & 56 & 100 & $\bullet$ & 0 \\
\hline 22.21 Women in labou force (\% female-male) & 84.5 & 77 & 43 & $\nabla$ & -7 & & & & & & \\
\hline 2222 Gender pay gap (\$ of employees) & n/a & n/a & n/a & & & & & & & & \\
\hline 2223 Capacity to attract and retain talent $(1-7$ survey) & 3.5 & 45 & 59 & $\Delta$ & 17 & & & & & & \\
\hline 22.24 Knowledge insentive employment (*) & $n / a$ & $n / a$ & n/a & & & & & & & & \\
\hline
\end{tabular}




\section{Index 2020}

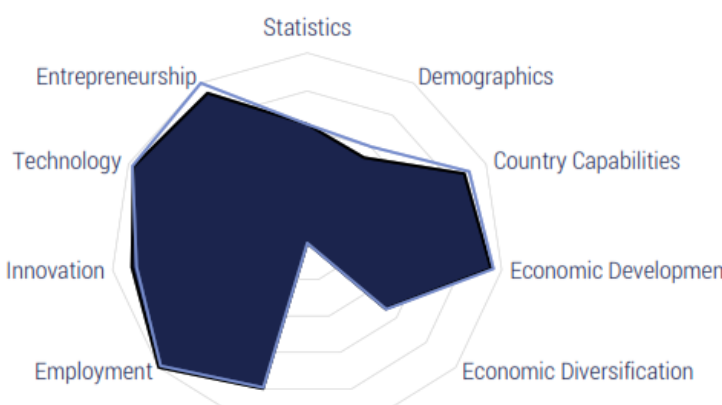

Education and Skills

Inequality

- GLRI 2020

口GLRI 2015

Note: the score of the Inequality sub-pillar for GLRI 2015 and GLRI 2020 is equal to 0 due to the lack of data for the corresponding indicators.

\begin{tabular}{|c|c|c|c|c|c|c|c|c|c|c|c|}
\hline \multicolumn{12}{|c|}{ Breakdown of Global Labour Resilience Results by Indicator } \\
\hline Variable & Value & Score & $\begin{array}{c}\text { GLRI } \\
2020 \text { rank }\end{array}$ & & $\begin{array}{l}\text { Rank change } \\
\text {-RI 2015-2020 }\end{array}$ & Variable & Value & Score & $\begin{array}{c}\text { GLRI } \\
2020 \text { rank }\end{array}$ & $\begin{array}{r}\text { Rank ct } \\
\text { GLRI } 201\end{array}$ & $\begin{array}{l}\text { change } \\
115-2020\end{array}$ \\
\hline 1. Structural Pillar & & 97 & 6 & $\nabla$ & 5 & 2.22 .5 Labour productivity (PPP) & 152418 & 100 & $T$ & - & 0 \\
\hline 1.1 Demographics & & 53 & 98 & $\nabla$ & 3 & 2.22 .6 ALP effectiveress (1-7 survey) & 5.6 & 97 & 4 & $\nabla$ & -2 \\
\hline 1.1.1 Share of older pepulatation ("s of total population) & 13.6 & 53 & 98 & $\nabla$ & -3 & 2.22.7 Labou-employer cooperation (1-7 survey) & 6.1 & 99 & 2 & - & 0 \\
\hline 1.2 Country Capabilities & & 88 & 5 & $\nabla$ & 1 & 2.22 .8 impact of taxes on workers (1-7 survey) & 6.2 & 100 & 1 & $\Delta$ & 3 \\
\hline 12.1 Eonnanic Complexity index & 1.8 & 88 & 5 & $\nabla$ & -1 & 2.22 .9 Earnings quality (PPP) & $n / a$ & $n / a$ & $n / a$ & & \\
\hline 1.3 Economic Development & & 95 & 2 & - & 0 & 2.22 .10 Quality of the working environment $(\%)$ & $n / a$ & $n / a$ & n/a & & \\
\hline 1.3 .1 lncome per capita (PPP) & 90091 & 100 & 1 & $\bullet$ & 0 & & & & & & \\
\hline 1.3.2 Dependence on natural tesources (\% of GDP) & 0.0 & 100 & 3 & $\nabla$ & -1 & 2.3 Innovation & & 90 & 4 & $\nabla$ & -1 \\
\hline 1.3.3 Tertiarisation of economy (\% of GDP) & 69.4 & 85 & 13 & $\nabla$ & -4 & 2.3 .1 Innovation input & & 88 & 10 & $\Delta$ & 3 \\
\hline 1.4 Economic Diversification & & 53 & 66 & $\nabla$ & 1 & 2.3.1.1 A\&D spendings (\% of GDP) & 2.2 & 80 & 12 & $\Delta$ & 4 \\
\hline 1.4. Concentration of exports & 0.2 & 75 & 73 & $\Delta$ & 2 & 2.3.1.21PR score & 8.4 & 95 & 5 & $\Delta$ & 2 \\
\hline 1.4 .2 Diversity & 169 & 31 & 62 & $\Delta$ & 3 & & & & & & \\
\hline 1.5 Inequality & & $n / a$ & na & & & 2.32 Innoration output & & 92 & 2 & - & 0 \\
\hline \multirow[t]{2}{*}{1.5 .1 income inequality } & n/a & $\mathrm{n} / \mathrm{a}$ & n/a & & & 2.32 .1 Trademark applications per th. pop. & 4.3 & 100 & 1 & $\bullet$ & 0 \\
\hline & & & & & & 2.3 .2 Patent applications pet th. pop. & 1.94 & 100 & 1 & $\bullet$ & 0 \\
\hline 2. Policy Pillar & & 97 & 2 & $\nabla$ & -1 & $2.32 .3 \mathrm{~A} 8 \mathrm{D}$ joumals per th. pop. & 200 & 100 & 1 & $\Delta$ & 5 \\
\hline 2.1 Education and skills & & 80 & 13 & - & 0 & 2.32 .4 Researchers in Rad per min.pop. & 6730 & 86 & 5 & $\nabla$ & -1 \\
\hline 21.1 Education and skills input & & $\pi 7$ & 19 & $\nabla$ & -2 & 2.3.2.5 Techricians in RSD per min pop. & 457 & 20 & 33 & $\Delta$ & 2 \\
\hline 21.1 .1 Government education spendings ( $\%$ of GDP) & 29 & 22 & 114 & $\nabla$ & -1 & 2.32 .6 Creative goods exponts (\% of goods exp.) & 3.88 & 80 & 15 & $\nabla$ & -1 \\
\hline 21.1.2 Tertiary public education spendings ("s of govexp) & 35.3 & 72 & 10 & $\bullet$ & 0 & & & & & & \\
\hline 21.1.3 Gov. and hh spending per tertiary student (PPPS) & na & $n / a$ & n/a & & & 2.4 Technology & & 97 & 4 & $\nabla$ & -1 \\
\hline 21.1.4 Years of schooling & 11.6 & 80 & 31 & $\Delta$ & 3 & 2.41 Technology input & & 84 & 30 & $\nabla$ & -19 \\
\hline \multirow[t]{2}{*}{ 21.1.5 Staff training (1-7 survey) } & 5.3 & 85 & 6 & $\nabla$ & -1 & 2.4.1.1 ICT affordability & 5.3 & 73 & 70 & $\nabla$ & -15 \\
\hline & & & & & & 2.4.1.2 ICT access index & 8.1 & 88 & 17 & $\nabla$ & -7 \\
\hline 2.1.2 Education and skills output & & 85 & 9 & $\Delta$ & 1 & & & & & & \\
\hline 2.21 Tertiary attainment rate ( $($ of $p 00$ 25+) & 31.6 & 68 & 11 & $\nabla$ & -1 & 2.42 Technology output & & 100 & 1 & - & 0 \\
\hline 21.22 PISA score & 556 & 91 & 2 & $\nabla$ & -1 & 2.42 .1 ICT goods and services export ("s of exp.) & 20.7 & $\pi$ & 18 & $\bullet$ & 0 \\
\hline 21.23 Skillset of graduates $(1.7$ survey) & 5.4 & 83 & 5 & - & 0 & 2.4.2.2Mobile broadband per 100 pop. & 144.6 & 89 & 4 & $\nabla$ & -3 \\
\hline 21.24 Skilled labour supply (1.7 survey) & 5.1 & 82 & 9 & $\Delta$ & 4 & & & & & & \\
\hline 21.25 Vocational entollinent ( $\%$ of students) & 11.6 & 25 & 64 & $\Delta$ & 3 & 2.5 Entrepreneurship & & 94 & 2 & $\nabla$ & -1 \\
\hline 21.26 Vocational enrollinent of $15-24$ odds (\%) & n/a & $n / a$ & n/a & & & 2.5.1 Entrepreneurstip input & & 96 & 3 & $\Delta$ & 1 \\
\hline 21.27 quality of vocational education (1-7 survey) & 5.3 & 72 & 8 & $\Delta$ & 1 & 2.5.1.1 Time dealing with gov. regulations (*) & $\mathrm{n} / \mathrm{a}$ & n/a & n/a & & \\
\hline 21.28 STEM graduates (\%) & 34.9 & 63 & 10 & $\nabla$ & -2 & 2.51.2 Time to start a business (days) & 1.5 & 98 & 2 & $\Delta$ & 1 \\
\hline 21.29 Digital skills (1-7 survey) & 5.7 & 95 & 6 & $\Delta$ & 1 & 2.5.1.3 Procedures to register a business & 2.0 & 92 & 3 & $\Delta$ & 2 \\
\hline 21.210 Critical thinking (1-7 survey) & 4.4 & 67 & 21 & $\nabla$ & -2 & 2.5 .1 .4 cost to start a business ( $\% \mathrm{GNI}$ per cap) & 0.5 & 93 & 11 & - & 0 \\
\hline 2.2 Employment & & 100 & 1 & $\Delta$ & 1 & 2.52 Entrepreneurship output & & 92 & 4 & $\nabla$ & -3 \\
\hline 22.1 Employment input & & 82 & 3 & $\Delta$ & 9 & 2.52 .1 Global Entrepreneurship Index & 527 & 59 & 25 & $\nabla$ & -16 \\
\hline 22.1 .1 Hiring and fring practices (1.7 survey) & 5.6 & 97 & 3 & $\nabla$ & -1 & 2.52 .2 New corporate registrations per th. pop. & 6.2 & 86 & 14 & $\nabla$ & -4 \\
\hline 22.1 .2 Worker's rights (1.7 soore) & 88.7 & 76 & 21 & $\Delta$ & 27 & 2.52 .3 Venture capital investments ( $\%$ of GDP) & n/a & $\mathrm{n} / \mathrm{a}$ & n/a & & \\
\hline 22.1.3 Hiring of foreign labour (1-7 survey) & 3.8 & 44 & 96 & $\Delta$ & 1 & 2.52 .4 SME outstanding loans (to of loans) & $\mathrm{n} / \mathrm{a}$ & n/a & n/a & & \\
\hline 2.2.1.4 Tax wedge (" of labour cost) & n/a & $n / a$ & n/a & & & 2.52 .5 Access to loans (1-7 survey) & 5.5 & 95 & 3 & - & 0 \\
\hline \multirow[t]{2}{*}{ 22.1.5 ALP spendings (s of GDP) } & n/a & $\mathrm{n} / \mathrm{a}$ & n/a & & & & & & & & \\
\hline & & & & & & 2.6 Statistics & & 62 & 79 & - & 0 \\
\hline 222 Employment output & & 100 & 1 & - & 0 & 2.6 .1 Statistical fullness (\%) & 0.81 & 62 & 79 & - & 0 \\
\hline 22.21 Women in labour force ( $\%$ female-male) & 793 & 71 & 67 & $\Delta$ & 5 & & & & & & \\
\hline 2222 Gender pay gap (\% of employees) & na & n/a & n/a & & & & & & & & \\
\hline 22.3 Capacity to attract and retain talent (1-7 survey) & 57 & 91 & 4 & - & 0 & & & & & & \\
\hline 22.24 Knowledge insentive emplioyment $(\%)$ & 527 & 85 & 2 & $\Delta$ & 1 & & & & & & \\
\hline
\end{tabular}


Appendix 4. The Global Talent Competitiveness ${ }^{14}$ Index 2020

\section{NIGERIA}

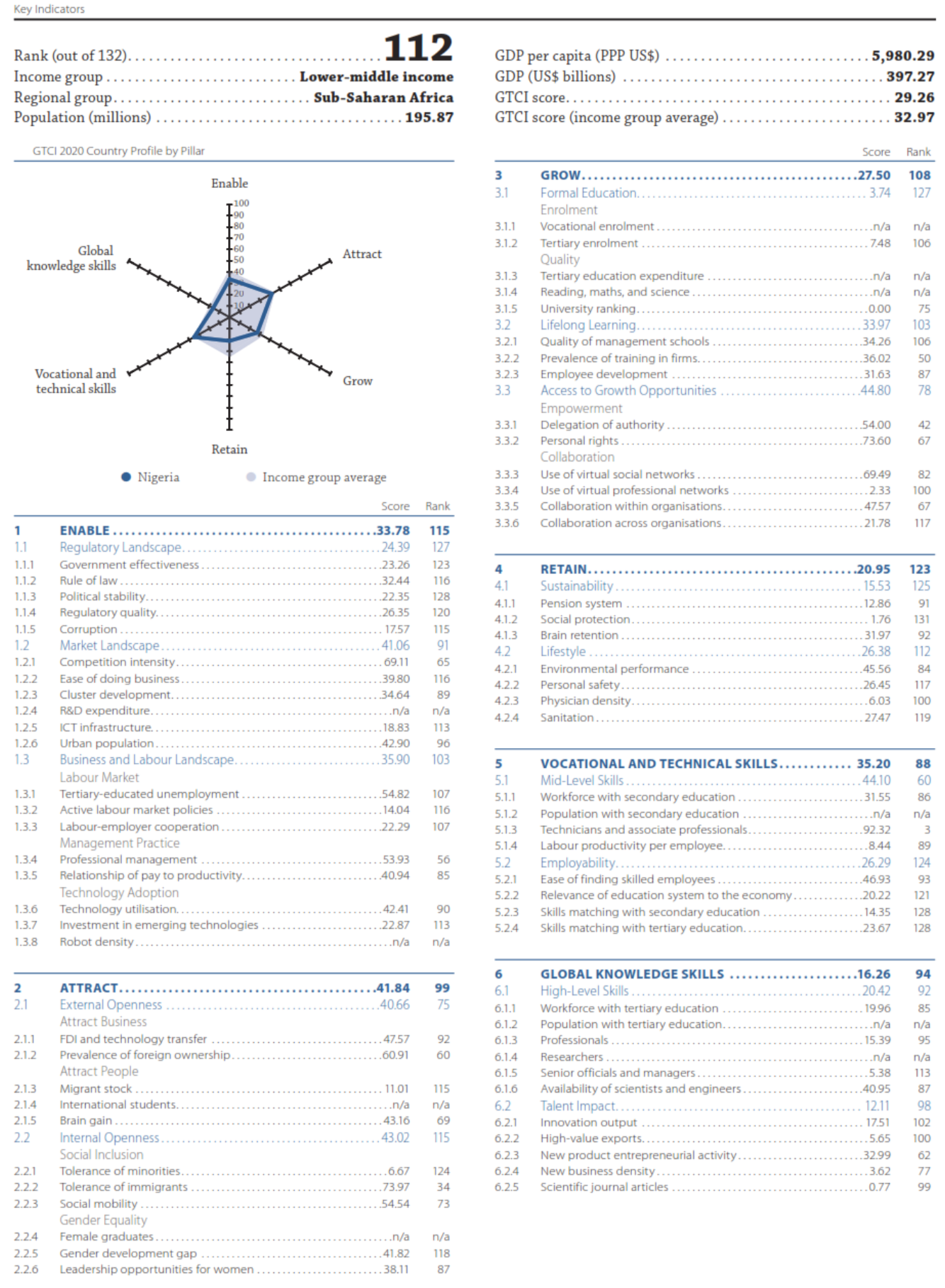

14. https://gtcistudy.com/ 


\section{SINGAPORE}

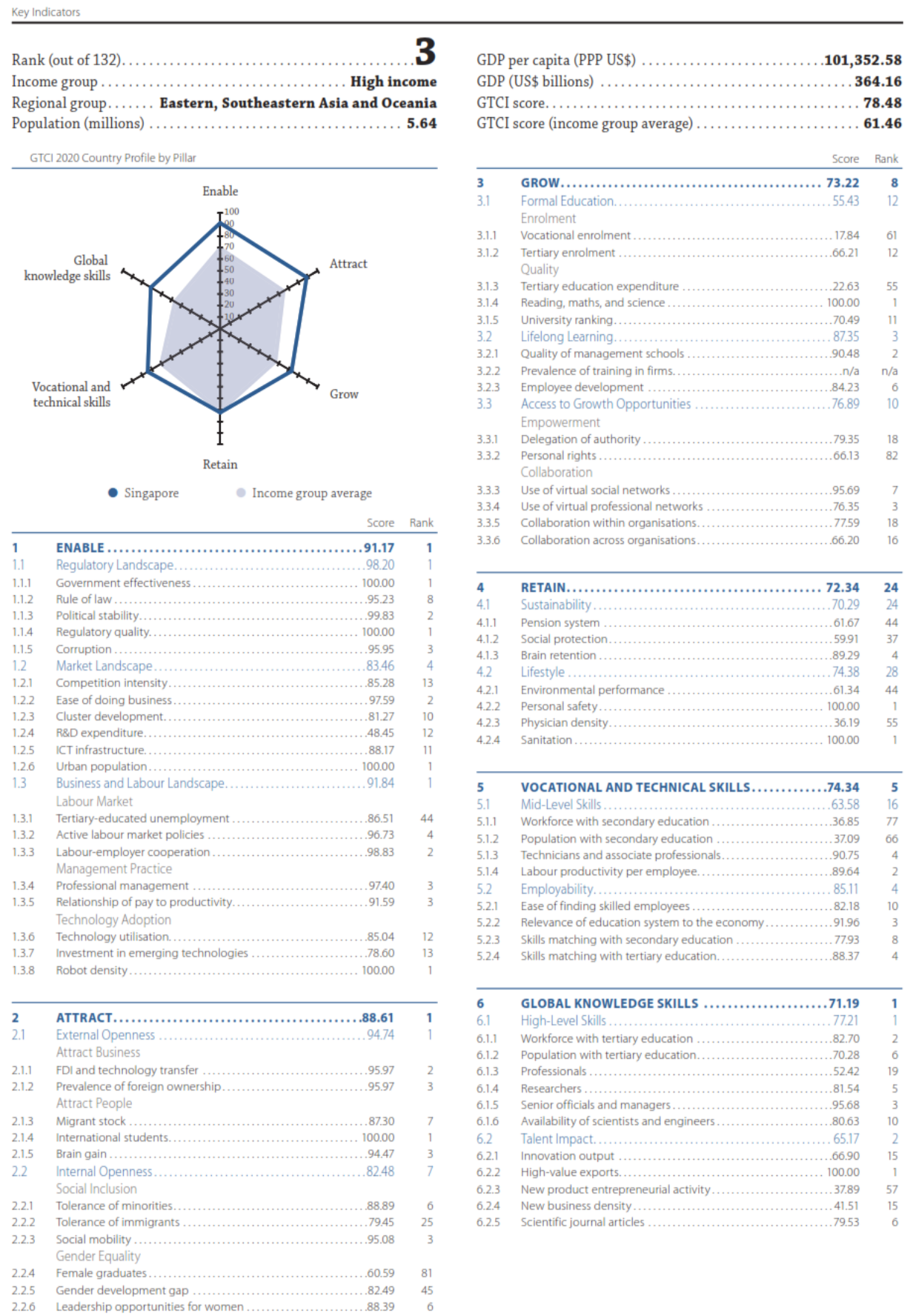




\section{Appendix 5. ERGP - Economic Recovery and Growth Plan}

Table 3. Selected Macroeconomic Projections, 2016-2020 (in per cent of GDP, unless otherwise specified). ${ }^{27}$

\begin{tabular}{|c|c|c|c|c|c|}
\hline & 2016 & 2017 & 2018 & 2019 & 2020 \\
\hline \multicolumn{6}{|l|}{ REAL } \\
\hline Real GDP Growth \% & -1.54 & 2.19 & 4.80 & 4.50 & 7.00 \\
\hline of which...Agriculture $\%$ & 4.69 & 5.03 & 7.04 & 7.23 & 8.37 \\
\hline of which...Industry \% & -10.13 & 7.74 & 6.11 & 6.07 & 8.02 \\
\hline of which...Services \% & -0.51 & -1.26 & 3.16 & 2.45 & 5.82 \\
\hline Non Oil GDP\% & -0.07 & 0.20 & 4.83 & 4.52 & 7.28 \\
\hline Oil GDP \% & -15.41 & 24.30 & 4.55 & 4.35 & 4.45 \\
\hline Gross National Disposable Income (GNDI) & 101.73 & 101.86 & 101.83 & 101.78 & 101.70 \\
\hline Gross National Income (GNI) & 97.48 & 97.67 & 97.77 & 97.88 & 97.91 \\
\hline Gross National Savings & 11.29 & 13.71 & 15.53 & 18.19 & 21.31 \\
\hline Total Consumption (C) & 90.44 & 88.14 & 86.30 & 83.59 & 80.39 \\
\hline Private Consumption $(C p)$ & 86.33 & 83.28 & 81.08 & 77.92 & 73.84 \\
\hline Government Consumption ( $\mathrm{Cg}$ ) & 4.11 & 4.86 & 5.22 & 5.67 & 6.55 \\
\hline Gross Domestic Investment (I) & 13.95 & 13.90 & 14.34 & 15.57 & 17.34 \\
\hline Government Investment (Ig) & 3.53 & 3.71 & 3.15 & 2.89 & 2.76 \\
\hline Private Investment (Ip) & 10.42 & 10.20 & 11.19 & 12.68 & 14.58 \\
\hline Inflation Rate \% & 18.55 & 15.74 & 12.42 & 13.39 & 9.90 \\
\hline Oil Price Benchmark US\$ & 38.00 & 42.50 & 45.00 & 50.00 & 52.00 \\
\hline Oil Production (mbpd) & 1.7 & 2.2 & 2.3 & 2.4 & 2.5 \\
\hline Labor Force growh rate \% & 3.66 & 3.92 & 4.37 & 3.98 & 4.09 \\
\hline Unemployment \% & 14.20 & 16.32 & 14.51 & 12.90 & 11.23 \\
\hline Unemployment inc underemployment rate $\%$ & 32.77 & 33.51 & 31.88 & 29.65 & 26.92 \\
\hline \multicolumn{6}{|l|}{ EXTERNAL } \\
\hline Current Account, n.i.e. & -1.84 & 0.65 & 1.96 & 2.59 & 2.89 \\
\hline Trade Balance & -0.31 & 1.80 & 2.85 & 3.26 & 3.42 \\
\hline Capital and Financial Accounts & 1.02 & 1.32 & 1.35 & 1.28 & 1.34 \\
\hline of which: FDI & 0.21 & 0.22 & 0.33 & 0.33 & 0.43 \\
\hline$P I$ & 0.85 & 1.14 & 1.06 & 0.98 & 0.95 \\
\hline Overall Balance & 1.38 & -2.11 & -3.43 & -3.99 & -4.34 \\
\hline Net Factor Income Payments (Yf) & -2.52 & -2.33 & -2.23 & -2.12 & -2.09 \\
\hline Exports of goods and services $(X)$ & 9.01 & 10.82 & 11.52 & 11.39 & 11.66 \\
\hline .....of which exports of goods & 8.38 & 10.23 & 10.95 & 10.85 & 11.13 \\
\hline Imports of goods and services (M) & -12.58 & -12.03 & -11.40 & -10.58 & -10.47 \\
\hline .....of which imports of goods & -8.69 & -8.43 & -8.11 & -7.59 & -7.71 \\
\hline
\end{tabular}

${ }^{27}$ Federal Republic of Nigeria Economic Recovery \& Growth Plan 2017-2020 Ministry of Budget \& National Planning February, 2017.

https://nigeriaembassygermany.org/mosaic/_M_userfiles/Economic-Recovery-Growth-Plan-2017-2020.pdf 
Table 4. (Cont'd) - selected macroeconomic projections, 2016-2020 (in per cent of GDP. Unless otherwise specified), ${ }^{27}$

\begin{tabular}{|c|c|c|c|c|c|}
\hline & 2016 & 2017 & 2018 & 2019 & 2020 \\
\hline \multicolumn{6}{|l|}{ REAL } \\
\hline Real GDP Growth \% & -1.54 & 2.19 & 4.80 & 4.50 & 7.00 \\
\hline of which...Agriculture \% & 4.69 & 5.03 & 7.04 & 7.23 & 8.37 \\
\hline of which...Industry $\%$ & -10.13 & 7.74 & 6.11 & 6.07 & 8.02 \\
\hline of which...Services \% & -0.51 & -1.26 & 3.16 & 2.45 & 5.82 \\
\hline Non Oil GDP \% & -0.07 & 0.20 & 4.83 & 4.52 & 7.28 \\
\hline Oil GDP \% & -15.41 & 24.30 & 4.55 & 4.35 & 4.45 \\
\hline Gross National Disposable Income (GNDI) & 101.73 & 101.86 & 101.83 & 101.78 & 101.70 \\
\hline Gross National Income (GNI) & 97.48 & 97.67 & 97.77 & 97.88 & 97.91 \\
\hline Gross National Savings & 11.29 & 13.71 & 15.53 & 18.19 & 21.31 \\
\hline Total Consumption $(C)$ & 90.44 & 88.14 & 86.30 & 83.59 & 80.39 \\
\hline Private Consumption (Cp) & 86.33 & 83.28 & 81.08 & 77.92 & 73.84 \\
\hline Government Consumption (Cg) & 4.11 & 4.86 & 5.22 & 5.67 & 6.55 \\
\hline Gross Domestic Investment (I) & 13.95 & 13.90 & 14.34 & 15.57 & 17.34 \\
\hline Government Investment (Ig) & 3.53 & 3.71 & 3.15 & 2.89 & 2.76 \\
\hline Private Investment (Ip) & 10.42 & 10.20 & 11.19 & 12.68 & 14.58 \\
\hline Inflation Rate \% & 18.55 & 15.74 & 12.42 & 13.39 & 9.90 \\
\hline Oil Price Benchmark US\$ & 38.00 & 42.50 & 45.00 & 50.00 & 52.00 \\
\hline Oil Production (mbpd) & 1.7 & 2.2 & 2.3 & 2.4 & 2.5 \\
\hline Labor Force growh rate \% & 3.66 & 3.92 & 4.37 & 3.98 & 4.09 \\
\hline Unemployment $\%$ & 14.20 & 16.32 & 14.51 & 12.90 & 11.23 \\
\hline Unemployment inc underemployment rate\% & 32.77 & 33.51 & 31.88 & 29.65 & 26.92 \\
\hline \multicolumn{6}{|l|}{ EXTERNAL } \\
\hline Current Account, n.i.e. & -1.84 & 0.65 & 1.96 & 2.59 & 2.89 \\
\hline Trade Balance & -0.31 & 1.80 & 2.85 & 3.26 & 3.42 \\
\hline Capital and Financial Accounts & 1.02 & 1.32 & 1.35 & 1.28 & 1.34 \\
\hline of which: FDI & 0.21 & 0.22 & 0.33 & 0.33 & 0.43 \\
\hline$P I$ & 0.85 & 1.14 & 1.06 & 0.98 & 0.95 \\
\hline Overall Balance & 1.38 & -2.11 & -3.43 & -3.99 & -4.34 \\
\hline Net Factor Income Payments (Yf) & -2.52 & -2.33 & -2.23 & -2.12 & -2.09 \\
\hline Exports of goods and services $(X)$ & 9.01 & 10.82 & 11.52 & 11.39 & 11.66 \\
\hline .....of which exports of goods & 8.38 & 10.23 & 10.95 & 10.85 & 11.13 \\
\hline Imports of goods and services (M) & -12.58 & -12.03 & -11.40 & -10.58 & -10.47 \\
\hline .....of which imports of goods & -8.69 & -8.43 & -8.11 & -7.59 & -7.71 \\
\hline
\end{tabular}

\section{Sources: MBNP, NBS, FMF and CBN}

CBN - Central Bank of Nigeria

BRICS - Brazil, Russia, India, China, South Africa

MBNP - Ministry of Budget and National Planning

NBS - National Bureau of Statistics

ERGP - Economic Recovery and Growth Plan

SIP - Strategic Implementation Plan. 
Table 5. Nigeria's HDI trends based on consistent time series data and new goalposts

\begin{tabular}{|c|c|c|c|c|c|}
\hline & $\begin{array}{c}\text { Life } \\
\text { expectancy at } \\
\text { birth }\end{array}$ & $\begin{array}{c}\text { Expected } \\
\text { years of } \\
\text { schooling }\end{array}$ & $\begin{array}{c}\text { Mean years of } \\
\text { schooling }\end{array}$ & $\begin{array}{c}\text { GNI per capita } \\
\text { (2017 PPP\$) }\end{array}$ & HDI value \\
\hline 1990 & 45.9 & 6.7 & & 3,109 & \\
\hline 1995 & 45.9 & 7.2 & & 2,776 & \\
\hline 2000 & 46.3 & 8.0 & & 2,739 & \\
\hline 2005 & 48.3 & 9.0 & 5.2 & 3,675 & 0.465 \\
\hline 2010 & 50.9 & 8.4 & 5.2 & 4,636 & 0.482 \\
\hline 2015 & 53.1 & 9.7 & 6.2 & 5,356 & 0.526 \\
\hline 2016 & 53.5 & 9.5 & 6.3 & 5,160 & 0.526 \\
\hline 2017 & 54.0 & 9.7 & 6.4 & 5,032 & 0.531 \\
\hline 2018 & 54.3 & 9.7 & 6.5 & 4,929 & 0.534 \\
\hline 2019 & 54.7 & 10.0 & 6.7 & 4,910 & 0.539 \\
\hline
\end{tabular}

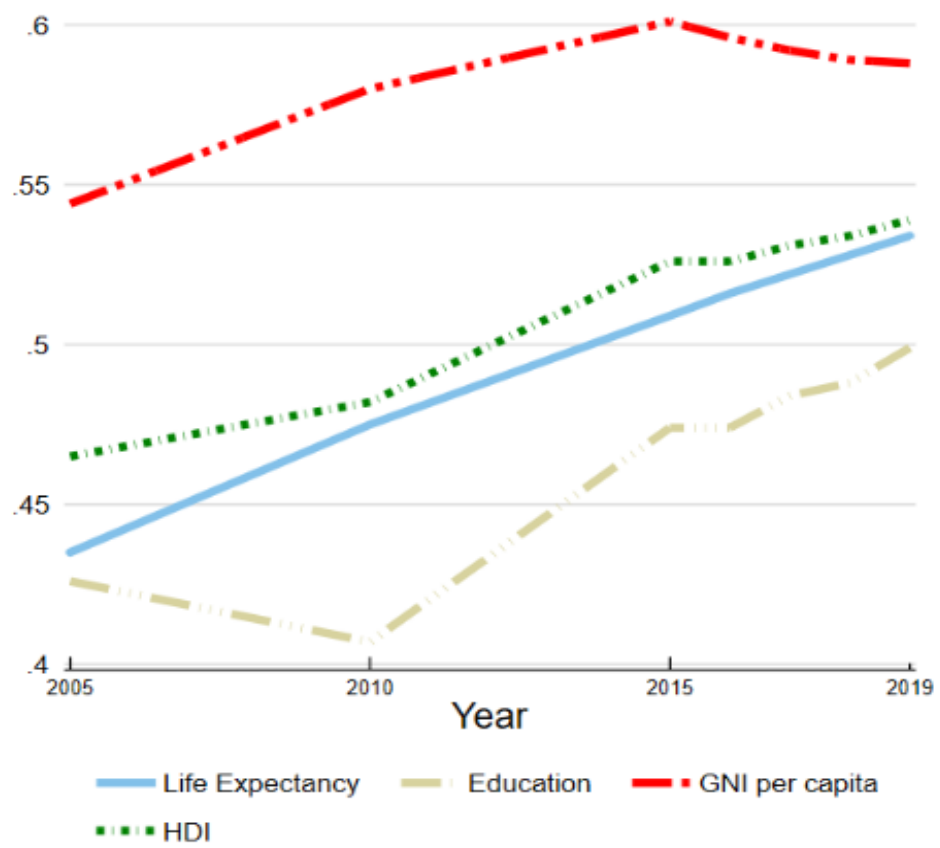

Figure 4 | Trends in Nigeria's HDI component indices 2005-2019.

\section{Notes}

It is misleading to compare values and rankings with those of previously published reports, because of revisions and updates of the underlying data and adjustments to goalposts. Readers are advised to assess progress in HDI values by referring to Table 2 ('Human Development Index Trends') in the 2020 Human Development Report. Table 2 is based on consistent indicators, methodology and time-series data and, thus, shows real changes in values and ranks over time, reflecting the actual progress countries have made. Small changes in values should be interpreted with caution as they may not be statistically significant due to sampling variation. Generally speaking, changes at the level of the third decimal place in any of the composite indices are considered insignificant. Unless otherwise specified in the source, tables use data available to HDRO as of 15 July 2020. All indices and indicators, along with technical notes on the calculation of composite indices, and additional source information are available online at http://hdr.undp.org/en/data. For further details on how each index is calculated please refer to Technical Notes 1-6 and the associated background papers available on the Human Development Report website: http://hdr.undp.org/en/data. 
Appendix 6. Global Labour Resilience Index (GLRI) 2020

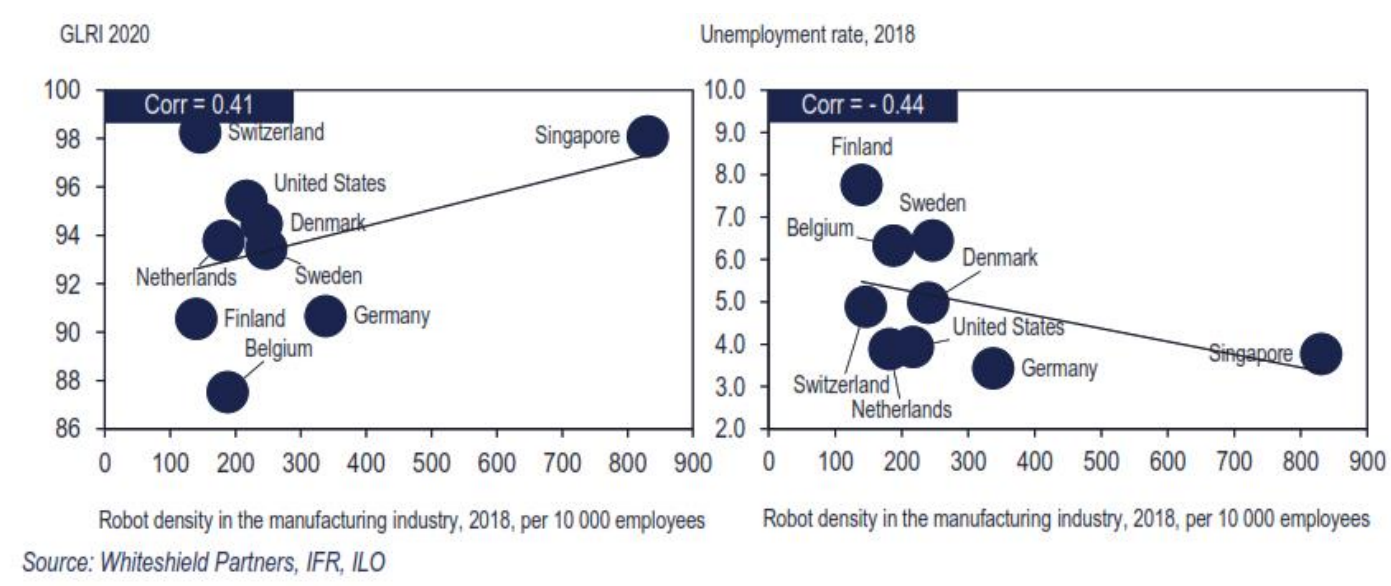

Figure 5 | GLRI and unemployment rate versus robot density manufacturing.

\section{Appendix 7 - Human Development Index (HDI)}

The HDI is a summary measure for assessing long-term progress in three basic dimensions of human development's a long and healthy life, access to knowledge and a decent standard of living. A long and healthy life is measured by life expectancy. Knowledge level is measured by mean years of schooling among the adult population, which is the average number of years of schooling received in a life-time by people aged 25 years and older; and access to learning and knowledge by expected years of schooling for children of school-entry age, which is the total number of years of schooling a child of school-entry age can expect to receive if prevailing patterns of age-specific enrolment rates stay the same throughout the child's life. Standard of living is measured by Gross National Income (GNI) per capita expressed in constant 2017 international dollars converted using purchasing power parity (PPP) conversion rates To ensure as much cross-country comparability as possible, the HDI is based primarily on international data from the United Nations Population Division (the life expectancy data), the United Nations Educational, Scientific and Cultural Organization Institute for Statistics (the mean years of schooling and expected years of schooling data) and the World Bank (the GNI per capita data). As stated in the introduction, the HDI values and ranks in this year's report are not comparable to those in past reports because of some revisions to the component indicators. To allow for assessment of progress in HDIs, the 2020 Human Development Report includes recalculated HDIs from 1990 to 2019 using consistent series of data.

\section{Nigeria's HDI value and rank *}

Nigeria's HDI value for 2019 is 0.539 which put the country in the low human development category-positioning it at 161 out of 189 countries and territories. Between 2005 and 2019, Nigeria's HDI value increased from 0.465 to 0.539 , an increase of 15.9 percent. Table 5 and Figure 4 reviews Nigeria's progress in each of the HDI indicators. Between 1990 and 2019, Nigeria's life expectancy at birth increased by 8.8 years, mean years of schooling increased by 1.4 years and expected years of schooling increased by 3.3 years. Nigeria's GNI per capita increased by about 58.0 percent between 1990 and 2019.

\footnotetext{
* Throughout this note, the term country refers to countries or UN-recognized territories. Human Development Report 2020 The Next Frontier: Human Development and the Anthropocene Briefing note for countries on the 2020 Human Development Report.
} 